\title{
1 Coherent sea level variation in and around the Sea of Okhotsk
}

2

3 Takuya Nakanowatari *, Kay I. Ohshima

4

5 Institute of Low Temperature Science, Hokkaido University, Sapporo, Japan

6

$7 \quad *$ Corresponding author address.

8 Institute of Low Temperature Science, Hokkaido University

9 Kita-19, Nishi-8, Sapporo, 060-0819 Japan

10 Tel.:+81-11-706-5497; fax:+81-11-706-5497

11 E-mail address: nakano@lowtem.hokudai.ac.jp (T. Nakanowatari).

(C) 2014. This manuscript version is made available under the Elsevier user license http://www.elsevier.com/open-access/userlicense/1.0/ 


\section{ABSTRACT}

We investigated the seasonal and interannual variations of the sea level in and around the Sea of Okhotsk and their causes, based on tide gauge and satellite altimeter data. The sea level all along the coastal region of the Sea of Okhotsk is found to be dominated by the seasonal variation with a maximum in winter and a minimum in summer, which cannot be explained by the annual cycle of atmospheric heat flux and pressure. This sea level variation appears to reflect ocean current variations. Both the Arrested Topographic Waves (ATWs) caused by alongshore wind stress and the Sverdrup transport by wind stress curl show corresponding seasonal variations. Seasonal amplitude of the sea level is relatively large along Sakhalin Island with a tendency of a larger amplitude toward the south. This meridional dependence is consistent with the ATWs, but not with the Sverdrup transport in the Sea of Okhotsk. Seasonal variation of the geostrophic current velocity expected from the sea level variation is comparable to that of the observed nearshore current and is consistent with the theoretical ATW transport. It is also revealed that, on an interannual timescale, the wintertime sea level fluctuates quite coherently all around the Sea of Okhotsk and further along the East Kamchatka and Oyashio coasts in the North Pacific. The altimeter data clearly show that this coherent sea level variation is trapped over the coastal and continental shelf regions with depths shallower than 1000 m. The wintertime sea levels have a higher correlation with the ATW transport than with the Sverdrup transport in the Sea of Okhotsk and the upstream East Kamchatka coast. All these suggest that the interannual sea level variation along the coastal and shelf regions in winter, as well as the seasonal variation, is mainly caused by the ATWs (coastal trapped current forced by the alongshore wind stress). The wintertime 
36 Sverdrup transport, raised by the previous studies, is the secondary contributor to 37 these variations. 


\section{Introduction}

The Sea of Okhotsk is a marginal sea located on the northwest rim of the Pacific

Ocean, connected through the Kuril Straits (Fig. 1). The surface ocean circulation is mainly characterized by a cyclonic circulation with a western boundary current along the east Sakhalin, which is called the East Sakhalin Current (ESC) (Leonov, 1960; and also reviewed by Talley and Nagata, 1995). The ESC has two velocity cores: one exists near the coast and the other over the shelf slope (Ohshima et al., 2002). The annual mean volume transport of the ESC is estimated as $7.0 \mathrm{~Sv}$ with a large seasonal variation ranging from a maximum of $\sim 12 \mathrm{~Sv}$ in winter to a minimum of $\sim 2$ Sv in summer (Mizuta et al., 2003). The ESC has an important role in southward transport of cold dense shelf water, which is a source water of the North Pacific Intermediate Water (Shcherbina et al., 2004), iron, which is an essential nutrient for phytoplankton (Nishioka et al., 2007), and sea ice (Fukamachi et al., 2009).

The driving mechanism of the ESC has been examined in term of the ocean current driven by the wind stress in the Sea of Okhotsk. Simizu and Ohshima (2002) conducted a numerical simulation based on a barotropic ocean model with realistic topography. Their simulation indicates that the nearshore core of the ESC is well explained by the Arrested Topographic Waves (ATWs), which is induced by wind 
stress along the coast (Csanady, 1978). Ohshima et al. (2004) showed that the Sverdrup balance approximately holds for the cyclonic gyre over the northern half-basin of the Sea of Okhotsk $\left(50^{\circ}-53^{\circ} \mathrm{N}\right)$ and that a major part of the ESC can be regarded as the western boundary current of this gyre. An Ocean General Circulation Model (OGCM) simulation demonstrates that the two velocity cores of the ESC can be reproduced by the wind stress within the Sea of Okhotsk and quantitatively explained by the ATW and Sverdrup transport (Simizu and Ohshima, 2006).

Recent studies have suggested that ocean currents in the Sea of Okhotsk are also affected by the subarctic gyre in the North Pacific. Ohshima et al. (2010) showed that the water exchange between the Sea of Okhotsk and the North Pacific predominantly occurs during winter, with inflow through the northern straits and outflow through the southern straits. These features are qualitatively consistent with the Island Rule (Godfrey, 1989). Thus, it is likely that a part of the western boundary current of the subarctic gyre intrudes into the Sea of Okhotsk (Andreev and Shevchenko, 2008; Ohshima et al., 2010). Katsumata and Yasuda (2010) estimated the exchange transport based on the outputs from the OGCM for Earth Simulator (Masumoto et al., 2004) and hydrography in combination, and suggested that the water exchange reaches $\sim 10$ Sv in winter. 
The ocean circulation in the Sea of Okhotsk has been also investigated based on sea level variability. Satellite altimeter data have revealed the velocity core structure of the ESC (Ebuchi, 2006) and the annual cycle related to the strength of the anticyclonic circulation in the Kuril Basin (Uchimoto et al., 2008). Itoh and Ohshima (2000) showed that the tide gauge sea level along the northern coast of Hokkaido Island has remarkable seasonal variation, with a peak in winter. They suggested that the wintertime sea level increase is caused by the advent of fresh and cold ESC water. Such a seasonal variation has also been found on the North Pacific side of Hokkaido Island, and the effect of the ESC on the seasonal variation of the Coastal Oyashio was discussed (Isoda et al., 2003; Sakamoto et al., 2013).

Along the coast of Hokkaido Island, warm and saline water flows through the shallow Soya Strait as the Soya Warm Current. The Soya Warm Current is a part of the Tsushima Warm Current System in the Sea of Japan and driven by the sea level difference between the Sea of Okhotsk and the Sea of Japan (Aota, 1975; Ohshima, 1994; Matsuyama et al., 2006). Therefore, there is a possibility that the sea level fluctuation in the Sea of Okhotsk is related to the strength of the Soya Warm Current and further the Tsushima Warm Current. Tsujino et al. (2008) proposed that the seasonal variability of the Tsushima Warm Current as well as the Soya Warm Current 
93 is controlled by the sea level set up by the ATWs along the coast of the Sea of

94 Okhotsk, based on an OGCM simulation and analytical model.

95 In the subarctic North Pacific, it is known that sea level variability along the

96 western coast is well explained by the barotropic response of wind-driven gyre

97 circulation on seasonal to interannual timescales (Isoguchi et al., 1997; Ito et al.,

98 2004; Isoguchi and Kawamura, 2006). Isoguchi and Kawamura (2006) showed that

99 the coastal sea level rises in winter and lowers in summer in accordance with the

100 strength of the East Kamchatka Current (EKC), based on tide gauge and satellite

101 altimeter data. Ito et al. (2004) evaluated the interannual variability of the Oyashio

102 transport by comparing satellite altimeter data with repeated hydrography and

103 mooring observations and found that it is partly explained by the Sverdrup transport.

104 On the other hand, most of the sea surface in the Sea of Okhotsk is covered by

105 sea ice in winter. Therefore, examination of the sea level variability has been limited

106 to seasons with no ice (Ebuchi, 2006) or the southern area (Uchimoto et al., 2008).

107 Examination of the sea level variability over a whole year has been limited to the tide

108 gauge data collected along Hokkaido Island (Konishi et al., 1986; Itoh and Ohshima,

109 2000; Isoda et al., 2003; Andreev and Shevchenko, 2008) and Kuril Islands (Sedaeva

110 and Shevchenko, 2001). Shevchenko and Romanov (2005) analyzed the 
111 Topex/Poseidon satellite altimetry data to investigate seasonal changes in the

112 circulation of the Sea of Okhotsk. However, the cause of seasonal and interannual

113 variations of sea level has not yet been fully examined.

114 In this study, we examine tide gauge data mainly provided by the Far Eastern

115 Regional Hydrometeorological Research Institute (FERHRI) and satellite altimeter

116 data to clarify seasonal and interannual variations of the sea level in and around the

117 Sea of Okhotsk. As will be shown, the sea level all along the coastal region of the Sea

118 of Okhotsk shows similar seasonal variation and the coherent variation in winter. This

119 coherent variation extends further into the surrounding coastal areas in the North

120 Pacific. These results imply that the sea level variation in and around the Sea of

121 Okhotsk is related to the ocean current change.

122 The paper is organized in the following manner. Data and methods are described

123 in Section 2. In Section 3, seasonal and interannual variations of the sea level in and

124 around the Sea of Okhotsk are examined based on tide gauge data and satellite

125 altimeter data. The cause of the sea level variation is explored with a focus on the

126 ocean currents related to wind stress change. The relationship between the sea level

127 variation and atmospheric circulation changes is described in Section 4. In Section 5,

128 we discuss the effect of the ocean current change related to the sea level variation on 
129 the interannual variability of the sea ice extent in the Sea of Okhotsk. The summary

130 and discussion are presented in Section 6.

131

\section{2. Data and method}

133

Tide gauge data were provided by the FERHRI, and the Permanent Service for

Mean Sea Level (PSMSL) hosted by the Proudman Oceanographic Laboratory

(Woodworth, 1991). These data sets consist of monthly mean sea level records for 15 stations in and around the Sea of Okhotsk (Fig. 1 and Table 1). Most of the tide gauge

data are available from the 1950 s to 1990 s. To exclude the effect of the land

deformation by the earthquake in the Kuril Straits in 1994 (Lockridge, 1995), we used

the tide gauge data before 1993. In the tide gauge data from the FERHRI, there seem

to be no significant trends or abrupt changes caused by subsidence and earthquakes.

On the other hand, a remarkable increasing trend is found in the tide gauge data for

143 Kushiro provided by the PSMSL. Therefore, we removed this linear trend from the

144 time series for this station. The corrections for the inverse barometer effect caused by

145 changing atmospheric pressure were applied using sea level pressure data from the

146 NCEP/NCAR reanalysis data.

147 Altimeter data used in the present study were derived from the merged products 
148 of monthly mean sea surface height anomaly (SSHA) from Topex/Poseidon, Jason-1,

149 and European Research Satellite altimeter observations from 1993 to 2009. The sea

150 level anomalies are produced by the French Archiving, Validation, and Interpolation

151 of Satellite Oceanographic Data (AVISO) project using the mapping method of Ducet

152 et al. (2000). It is known that there is a possibility that the European Research Satellite

153 altimeter observations have an aliasing at the period of one year (Schlax and Chelton,

154 1994). However, the effect of this aliasing problem is expected to be small in and

155 around the Sea of Okhotsk (Uchimoto et al., 2008). The aliased tidal errors in the

156 AVISO altimetry data are relatively large for marginal seas such as the Sea of Okhotsk

157 (e.g., Morimoto, 2009). Significant tidal errors are considered to occur in the

158 northwestern shelf, the Shelikhov Gulf, and the Kuril Straits. For the northwestern

159 shelf and Shelikhov Gulf, we mask out the altimeter data, because sea ice covers these

160 areas in winter. For the Kuril Straits, we do not discuss the results based on the

161 altimeter data.

162 To examine the sea level response to wind forcing, we used ERA-40 data from

1631958 to 2001 (Uppala et al., 2005). For the Sea of Okhotsk, the high-resolution

164 version with a spatial resolution of $1.125^{\circ}$ in latitude and longitude was used. The

165 monthly mean wind stress $\tau=\left(\tau_{\mathrm{x}}, \tau_{\mathrm{y}}\right)$ is calculated from 6 hourly wind data based on a 
bulk formula as follows:

$$
\vec{\tau}=\rho C_{D}|\vec{v}| \vec{v}
$$

where $\rho$ is the surface air density, $C_{\mathrm{D}}$ is the drag coefficient, and $\vec{v}$ is the wind vector. For $C_{\mathrm{D}}$, we adopt a stability-independent drag coefficient of Large and Pond (1981) as follows:

$$
\begin{array}{ll}
C_{D}=1.2 \times 10^{-3} & |\vec{v}| \leq 11.0 \mathrm{~m} \cdot \mathrm{s}^{-1}, \\
C_{D}=(0.49+0.065|\vec{v}|) \times 10^{-3} & |\vec{v}| \geq 11.0 \mathrm{~m} \cdot \mathrm{s}^{-1} .
\end{array}
$$

For the North Pacific, we used the monthly mean wind stress data with a resolution of $2.5^{\circ}$ in latitude and longitude from ERA-40.

In general, the drag coefficient for sea ice is somewhat larger than that for the ocean surface (Lepparanta, 2005). However, it is difficult to evaluate the effect of sea ice on wind stress applied to the ocean, because the ice-water drag coefficient and internal stress in ice cover are also related to the determination of the wind stress. Ohshima and Simizu (2008) showed that a general ocean circulation model with no ice reproduces the velocity field over the east Sakhalin shelf region very well. This result implies that the wind stress applied to the ocean does not change significantly regardless of the presence or absence of sea ice. In this paper, we calculated the wind stress based on a bulk formula for the open ocean without sea ice, even in winter. To assess our results, we also used the monthly mean wind stress data derived from the 
184 NCEP/NCAR reanalysis data, in which the roughness of sea ice area is accounted 185 for (Kanamitsu, 1989).

186 In mid- and low-latitude oceans, the sea level variations are dominated by the 187 thermosteric signal caused by seasonal density variations (Gill and Niiler, 1973). 188 Based on previous studies (Gill and Niiler, 1973; Vivier et al., 1999; Qiu, 2002), we 189 evaluated the thermosteric signal caused by local atmospheric heat flux. The 190 thermosteric signal was calculated from net surface heat flux data as follows:

$$
\frac{\partial \eta^{\prime}(t)}{\partial t}=\frac{\alpha}{\rho_{o} c_{p}}\{Q(t)-\overline{Q(t)}\}
$$

192 where $\rho_{0}$ is the reference density, $c_{\mathrm{p}}$ is the specific heat of sea water, and $\alpha$ is the 193 thermal expansion coefficient. The thermal expansion coefficient was calculated from 194 the temperature and salinity averaged over the mixed layer based on the World Ocean 195 Atlas 2005 (WOA05) (Antonov et al., 2006; Locarnini et al., 2006). As the mixed 196 layer depth, we adopted a constant value of $50 \mathrm{~m}$ depth which corresponds to the 197 typical seasonal thermocline depth in the Sea of Okhotsk (Ohshima et al., 2005). $Q(t)$ 198 is the net surface heat flux derived from the climatological monthly means of the 199 NCEP/NCAR reanalysis data during 1979 to 2008. The overbar denotes the annual 200 average of the climatological monthly means from January to December. The 201 estimated thermosteric values nearest to the tide gauge stations and satellite altimeter 
202 gridded point were used for evaluation of the thermosteric component for the 203 corresponding sea level data.

204

205

206

\section{Results}

We begin by showing the time series of raw monthly mean data from the tide gauges averaged over the Sakhalin coast (Fig. 2). We found a seasonal cycle with a clear maximum in winter and a minimum in summer. The timing of this seasonal cycle is out of phase with that of the altimeter SSH over the Kuril Basin (Uchimoto et al., 2008) and the North Pacific (e.g., Stammer, 1997). The interannual variability also has a large fraction on the sea level variability. For example, the wintertime peak of $22 \mathrm{~cm}$ in 1973/1974 season is about twice larger than that of $1972 / 1973$ season. Below, we will examine the seasonal and interannual sea level variations individually.

\subsection{Seasonal variation}

To examine the seasonal variation of the sea level, the climatological monthly mean was calculated for each tide gauge. Figure 3a shows the annual cycle of the sea

level at each tide gauge. The most remarkable feature is the peak in December or 
221 January. This annual cycle is still evident after the thermosteric signal and inverse

222 barometer effect is removed from each tide gauge data (Fig. 3b). In addition to the

223 wintertime peak, the sea level along the northern coast of Hokkaido Island $(\mathrm{K}-\mathrm{O})$ and

224 the northern shelf of the Sea of Okhotsk $(B, C)$ have a secondary peak in September

225 (Fig. 3a). The secondary peak for the northern coast of Hokkaido Island is explained

226 by the seasonal variation of the Soya Warm Current (Itoh and Ohshima, 2000). On the

227 other hand, the secondary peak for the northern shelf might be related to the halosteric

228 component, because a relatively large river discharge occurs in summer near these

229 tide gauges (M, N) (e.g., Dai and Trenberth, 2002). Hereafter, the thermosteric and

230 inverse barometer effects are subtracted from the tide gauge data.

231 Next, we examined the spatial distribution of the seasonal amplitude with the

232 winter peak, using both the tide gauge and satellite altimeter data. Considering that

233 most of the tide gauge data show maximum peaks from December to January and

234 minimum peaks from April to May (Fig. 3b), and that satellite altimeter data cannot

235 be used in the sea-ice covered season, the sea level difference between December and

236 May is adopted as a measure of the seasonal amplitude. The tide gauge data (Fig. 4a)

237 show that the seasonal amplitude is relatively large along Sakhalin Island (E, G, H, I,

$238 \mathrm{~J}$ ), with the difference value larger than $10 \mathrm{~cm}$. This result is consistent with the 
satellite altimeter data (Fig. 4b). On the other hand, the seasonal amplitude is much

240 smaller in the basin with depths greater than $1,000 \mathrm{~m}$ (see the depth contours in Fig.

241 1), indicating that the seasonal variation is confined to the coastal and shelf regions.

242 Since the seasonal variation of sea level in and around the Sea of Okhotsk is not

243 explained by the thermosteric height signal at all (Fig. 3b), the variation is suggested

244 to be related to dynamic response of the ocean current systems. Considering that the

245 high sea level season (winter) corresponds to the strong wind season and that the

246 seasonal amplitude is relatively large along the western boundary current region off

247 Sakhalin Island, the seasonal variation is likely caused by near-barotropically quick

248 responses through the ATWs and/or the western boundary current through the

249 Sverdrup transport (e.g., Ebuchi, 2006; Simizu and Ohshima, 2006). In winter,

250 northwesterly and northeasterly winds prevail over the western part of the Sea of

251 Okhotsk and the eastern part of the East Kamchatka Peninsula, respectively (Fig. 5a).

252 This wind pattern is favorable for the pile up of the Ekman transport to set up the

253 ATWs and the sea level rise along these coastal regions. In the western subarctic gyre

254 of the North Pacific, it has been suggested that the sea level along the western coast

255 increases in winter by intensification of the southward western boundary current

256 through the time-varying Sverdrup balance (Isoguchi and Kawamura, 2006). 
257 Similarly, the southward ESC in the Sea of Okhotsk also intensifies in winter (Mizuta

258 et al., 2003; Simizu and Ohshima, 2006). These results imply that the coastal sea level

259 along Sakhalin Island also may be affected by the compensation of the sea level

260 change in the offshore through the Sverdrup balance (Fig. 5b).

261 Therefore, we here examine the effects of ATW and Sverdrup transport on

262 seasonal sea level variations along Sakhalin Island. According to Csanady (1978), the

263 alongshore volume transport of the ATWs that occurs in a steady manner, $V_{\mathrm{ATW}}$, is

264 determined by:

265

$$
V_{A T W}=\int_{l_{1}}^{l_{2}} \frac{\tau_{l}}{\rho f} d l
$$

where a right-handed coordinate system is used with the $l$ axis along the coastline. $\tau_{l}$ is

267 the alongshore component of the wind stress, $\rho$ is the density of water, and $f$ is the

268 Coriolis parameter. On timescales larger than a month, the volume transport of the

269 coastally trapped flow is determined by Eq. (4), which can be derived from the linear

270 momentum equation (or vorticity equation) in a stationary state. This steady flow is

271 called the Arrested Topographic Waves (ATWs) by Csanady [1978]. A similar

272 equation was also used to examine the coastal sea level along the Alaska/Canada coast

273 (Qiu, 2002). This equation implies that the alongshore transport at $l_{1}$ is the sum of the

274 Ekman transport to or from the coast over the integral route from the starting point of 
$275 l_{2}$ to $l_{1}$. The integral route of the Ekman transport depends on several factors, such as

276 the shape of the coastline, shelf width, shelf slope, and bottom friction, which are

277 difficult to identify (Csanady, 1978). The OGCM simulation of the Sea of Okhotsk

278 indicates that the starting point of the integral route suitable for the ATW calculation

279 is the west of the Shelikhov Gulf (Fig. 1) (Simizu and Ohshima, 2002). However, the

280 effect of wind stress variability in the North Pacific was not included in their model

281 simulation. Since similar seasonal variations of the sea level are also found along the

282 northern coast of the Sea of Okhotsk and the eastern coast of the Kamchatka

283 Peninsula (Fig. 4), there is a possibility that the ATWs along Sakhalin Island is also

284 affected by wind stress over further upstream regions. Thus, we examine two

285 additional integral routes (routes 2 and 3, Fig. 5c) as well as the one (route 1)

286 proposed by Simizu and Ohshima (2002).

288 following equation:

$$
V_{S}=-\frac{1}{\beta \rho} \int_{x_{1}}^{x_{2}} \operatorname{curl} \vec{\tau} d x
$$

290 where the right-handed Cartesian coordinate system is adopted with $x$ and $y$ axes in

291 the eastward and northward directions, respectively. $\beta$ is the $y$ derivative of the

292 Coriolis parameter and $\vec{\tau}$ is a wind stress vector. The integral route is taken along 
293 latitudinal lines from the eastern boundary $\left(x_{2}\right)$ to the western boundary $\left(x_{1}\right)$, where

294 the eastern boundary is defined as the west coast of the Kamchatka Peninsula and the

295 Kuril Islands (Fig. 5b). Northward Sverdrup transport is defined as positive. Several

296 studies imply that a part of the EKC intrudes into the Sea of Okhotsk through the

297 northern part of the Kuril Straits and that the inflow is significantly correlated with the

298 Sverdrup transport in the North Pacific (Andreev and Shevchenko, 2008; Ohshima et

299 al., 2010). To evaluate the variability of the inflowing water from the Pacific, we also

300 examined the Sverdrup transport over the North Pacific, integrated from the eastern

301 boundary of the North Pacific. The Sverdrup transport in each basin is meridionally

302 averaged over $46^{\circ}-50^{\circ} \mathrm{N}$.

303 Figure 6 compares the seasonal variation of the sea level along Sakhalin Island

304 with that of the ATW transport and Sverdrup transport. As the representative for the

305 sea level, we show the climatological monthly values averaged over 6 tide gauge

306 stations (D-J) (Fig. 6a). For the ATW, the climatological values from 1979 to 2008 for

307 routes 1, 2, and 3 are shown (Fig. 6b). For the Sverdrup transport, the climatological

308 values for both the Sea of Okhotsk and the North Pacific are shown (Fig. 6c). Both the

309 ATW transport and Sverdrup transport show a maximum from December to January

310 and a minimum from June to August, although the absolute value of the volume 
transport is rather different among these transports. These seasonal variations are also

312 similar to those of the sea level along Sakhalin Island. Similar results are obtained

313 using the NCEP/NCAR reanalysis data, although the seasonal amplitude of the ATW

314 transport calculated using the NCEP/NCAR reanalysis data is somewhat larger than

315 that using the ERA-40 data (not shown).

316 Next, we compare the latitudinal dependence of the seasonal sea level variation

317 from $46^{\circ}$ to $52^{\circ} \mathrm{N}$ with those of the corresponding ATW transport and Sverdrup

318 transport. The ATW transport at each latitude is calculated based on the wind stress

319 along route 1 . The seasonal amplitude is evaluated from the difference of the

320 climatological value between December and May. The seasonal amplitude of the sea

321 level tends to be larger in lower latitudes (Fig. 7a). This latitudinal dependence is

322 consistent with that of the ATW (Fig. 7b). The larger seasonal variation of the ATW in

323 the southern areas is caused by the prevailing southward wind along Sakhalin Island

324 in winter (Fig. 5a). On the other hand, the latitudinal dependence of the Sverdrup

325 transport in the Sea of Okhotsk is contrary to that of the sea level. The latitudinal

326 dependence of the seasonal sea level variation is not qualitatively explained by the

327 Sverdrup transport.

328 The above analyses suggest that the seasonal variation of the sea level along 
329 Sakhalin Island is dominated by the ATWs. To quantify this suggestion, we evaluated

330 the geostrophic current from the sea level data and compare it with the current

331 velocity data obtained from mooring measurements (Mizuta et al., 2004) and the

332 theoretical ATW transport. Assuming that the seasonal current variation is barotropic,

333 the seasonal amplitude of the geostrophic current speed $\Delta v$ is calculated as follows:

$$
\Delta \mathrm{v}=\frac{g}{f} \cdot \frac{\Delta\left(\eta_{\mathrm{c}}-\eta_{0}\right)}{\Delta \mathrm{x}}
$$

335 where $\Delta x$ is the width of the ATW, $g$ is gravity acceleration $\left(9.8 \mathrm{~m} \mathrm{~s}^{-2}\right), f$ is the Coriolis

336 parameter $\left(1.2 \times 10^{-4} \mathrm{~s}^{-1}\right)$, and $\Delta\left(\eta_{\mathrm{c}}-\eta_{\mathrm{o}}\right)$ is the seasonal amplitude of the sea level

337 difference between the coast and the offshore, where the offshore sea level is assumed

338 to be constant.

339

Based on the observed current structure from the surface drifters (Ohshima et al.,

340 2002) and the simulated result of the nearshore branch of the ESC using an OGCM

341 (Simizu and Ohshima, 2006), the width of the ATW $\Delta x$ is assumed to be $\sim 70 \mathrm{~km}$.

342 Since the difference between the monthly mean sea levels along Sakhalin Island in

343 January and April is about $14 \mathrm{~cm}$ (Fig. 6a), the seasonal amplitude of the surface

344 velocity $\Delta v$ would be $\sim 16 \mathrm{~cm} \mathrm{~s}^{-1}$ according to the geostrophic balance (Eq. 6). Since

345 the monthly mean velocity obtained from the mooring measurement at $53^{\circ} \mathrm{N}$ showed

346 that the difference between the southward current velocity near the coast in January 
347 and April is $\sim 20 \mathrm{~cm} \mathrm{~s}^{-1}$ (Fig. 6 of Mizuta et al., 2003), the seasonal amplitude of the

348 estimated value is comparable to the observed value.

349 When the thickness $H$ of the ATW is assumed to be $100 \mathrm{~m}$, which is the mean

350 water depth over the width of the ATW (from the coast to $70 \mathrm{~km}$ offshore in latitudes

351 of $\left.46^{\circ}-52^{\circ} \mathrm{N}\right)$, the seasonal variation of the volume transport $(\Delta v \times \mathrm{H} \times \Delta x)$ is

352 estimated to be $\sim 1.3 \mathrm{~Sv}$ using the velocity difference $\left(\Delta v=20 \mathrm{~cm} \mathrm{~s}^{-1}\right)$ measured from

353 the moorings. The seasonal variation of the theoretical ATW transport calculated using

354 the wind stress along routes 1,2 , and 3 is 0.95 (1.6), 0.85 (1.2), and 2.5 (3.0) Sv,

355 respectively (The brackets show the theoretical ATW transport for the same routes

356 calculated using the NCEP/NCAR reanalysis data). Hence, the orders of the

357 theoretical values are comparable to the estimated values.

358 We also evaluate the contribution of the offshore (western boundary current)

359 component of the ESC to the seasonal sea level variation. From the vertical cross

360 sections of the monthly mean velocity field obtained from the mooring measurement

361 (Mizuta et al., 2003), the southward current speed of the offshore component at the

362 surface is $\sim 25 \mathrm{~cm} \mathrm{~s}^{-1}$ and $\sim 15 \mathrm{~cm} \mathrm{~s}^{-1}$ in January and April, respectively. Since the

363 zonal width of the offshore ESC component is $\sim 50 \mathrm{~km}$ (Mizuta et al., 2003), the sea

364 level rise toward the coast by this current is estimated to be $\sim 15 \mathrm{~cm}$ and $\sim 9 \mathrm{~cm}$ in 
365 January and April, respectively. Since the difference between the estimated sea level

366 in January and April $(6 \mathrm{~cm})$ is smaller than that of the observed sea level difference

$367(14 \mathrm{~cm})$, the seasonal variation of the sea level is insufficiently explained by the

368 Sverdrup transport. As well as the latitudinal dependence of the seasonal amplitude,

369 these comparisons on the basis of the geostrophic balance imply that the ATWs are the

370 primary contributor to the seasonal sea level variation and that the Sverdrup transport

371 is the secondary.

372

373 3.2. Interannual variation

374

375 In this section, we examine the interannual variability of the sea level, compared

376 to those of ATW and Sverdrup transports. For the examination of the interannual

377 variation, the climatological seasonal variation was removed from the tide gauge and

378 satellite altimeter data. The standard deviations of the monthly sea level anomalies in

379 winter (December to February) are considerably larger than those in the other seasons

380 (not shown). Wind speed and its interannual variability, a likely cause of the sea level

381 variation, are also large in winter. Thus, we mainly focus on the interannual variability

382 in winter. In this paper, the year of the wintertime from December 1969 to February

3831970 is defined as 1970 , and similarly for the other years. Figure 8 shows the time 
384 series of the wintertime tide gauge sea level anomalies from the East Kamchatka coast

385 (A), then all around the Okhotsk coast $(\mathrm{B}-\mathrm{N})$, and finally to the Oyashio coast $(\mathrm{O})$.

386 We found that the wintertime sea levels fluctuate quite coherently all around the Sea

387 of Okhotsk (B-N) with a remarkable year-to-year variability: positive anomalies in

$3881970,1974,1981$, and 1984 and negative anomalies in 1972, 1979, and 1982. It

389 should be noted that these coherent variations partly extend upstream to the East

390 Kamchatka coast (A) and downstream to the Oyashio coast (O).

391 To extract dominant modes for the interannual variability of tide gauge sea levels

392 in and around the Sea of Okhotsk, Empirical Orthogonal Function (EOF) analysis

393 based on a covariance matrix was applied to sea level data from 11 stations (A, B, E,

394 G, H, I, J, L, M, N, and O) at which continuous data were obtained from 1965 to 1988.

395 The first EOF mode for the wintertime sea level anomalies explains $61 \%$ of the total

396 variance, indicating that this mode is by far the dominant mode. The temporal

397 coefficient of the first EOF mode (PC-1) is shown at the bottom of Fig. 8. The spatial

398 structure of the first EOF mode shows all positive values with large values along

399 Sakhalin Island (Fig. 9a).

400 The interannual variability of the wintertime sea level is further examined using

401 satellite altimeter data. We used the SSHA averaged in December, because the 
402 altimeter data are not fully available for the sea ice seasons from January to February.

403 Figure $9 \mathrm{~b}$ shows the regression map of the SSHAs onto the time series of the 404 normalized SSHAs for the Sakhalin coast $\left(48^{\circ}-49^{\circ} \mathrm{N}, 143^{\circ}-144^{\circ} \mathrm{E}\right)$. The significant 405 positive correlations are found all over the shelf region with the water depths 406 shallower than 1,000 $\mathrm{m}$ in the Sea of Okhotsk (Fig. 1). The significant correlations are 407 also found further to the eastern shelf of the Kamchatka Peninsula and the Oyashio 408 coast in the North Pacific. The absolute values of the regression coefficients in these 409 regions are comparable to those for the tide gauge data. To explore the mechanism giving rise to the coherent sea level variation, we compared the interannual variability of the wintertime sea level along Sakhalin Island 412 with those of the ATW and Sverdrup transports. As an index of the sea level along 413 Sakhalin Island, we used the tide gauge data averaged over stations E, G, H, I, and J, 414 which is found to be quite similar to the PC-1 (the correlation between them is 0.98 ). 415 Table 2 summarizes the correlation coefficients between the sea level along Sakhalin 416 Island and the related volume transports. The wintertime sea level is significantly 417 correlated with both the ATW and Sverdrup transports in the Sea of Okhotsk, and the 418 former is larger than the latter. The result that the sea level has a higher correlation 419 with the ATW1 (ATW for route 1) than the ATW2, supports that the integral route 
proposed by Simizu and Ohshima (2002) is reasonable. Figure 10 shows the time series of the sea level anomalies and the ATW anomalies for route 1, demonstrating their good correspondence all through the analyzed period. It is noteworthy that the correlation between the sea level and ATWs for route 3 is also high (Table 2). The wind stress far from the east of Kamchatka and the Bering Sea may also contribute to the ATWs in the Sea of Okhotsk to some extent. Similar results are obtained using the NCEP/NCAR reanalysis data (Table 2). through the seasons. In Fig. 2, the time series of the monthly mean ATW transport for route 1 is superimposed on the sea level data. The timing and strength of the peaks of the ATW transport corresponds to those of the sea level anomalies. The correlation coefficients between the monthly mean of the sea level and the ATWs for routes 1 and 3 are 0.60 and 0.56 (significant at $95 \%$ confidence level), respectively. The correlations between the sea level and ATWs from spring to autumn are quite small

434 and insignificant (Table 3). Since the variance of the wind stress in these seasons is smaller than that in winter, it is likely that the contributions of other factors rather than

case. 

transport over the North Pacific and found the significant correlation between them on seasonal to interannual timescales. Ito et al. (2004) also indicated that year-to-year variability of the Oyashio transport is partly explained by the time-varying Sverdrup

transport. The present study suggests that the coherent sea level variation in the Sea of

Okhotsk extends to the coastal regions in the upstream EKC and the downstream examine the effect of the ATWs on the sea level variability in these western boundary current regions of the North Pacific. sea level data at Petropavlovsk-Kamchatsky (PK) and Kushiro (Fig. 1) from 1958 to

454 from starting points 3 and 1 to the locations of the tide gauges, respectively (Fig. 5c).

455 We conducted a correlation analysis between the sea level in winter and the ATWs and compare it with that for the Sverdrup transport in the North Pacific. 
transport $(r=0.15)$, suggesting that the sea level is affected by both transports. When

ATW and Sverdrup transports, the multiple correlation coefficient between the observed and predicted sea level becomes a significantly high value of 0.76 .

\section{Atmospheric circulation variability}


476 shows the regression map of the wind stress over the North Pacific onto the PC-1. The

477 northeasterly wind anomalies are found over the Sea of Okhotsk and the Bering Sea.

478 These wind stress anomalies induce Ekman transport anomalies over the coastal

479 region to pile up the sea level along Sakhalin Island and the east coast of the

480 Kamchatka Peninsula to generate the ATWs. The PC-1 is also significantly correlated

481 with the wind stress curl over the Sea of Okhotsk (Fig. 11b). This result indicates that

482 the northeasterly wind anomalies lead to the increase in both the ATW transport and

483 Sverdrup transport in the Sea of Okhotsk.

484 From the regression map of the sea level pressure, the northeasterly wind

485 anomalies related to the $\mathrm{PC}-1$ are also found to be related to the dipole pattern of the

486 high pressure over the Eurasian continent and the low pressure over the subtropics

487 (Fig. 11c). This anomalous sea level pressure pattern resembles the negative phase of

488 the Western Pacific (WP) pattern dominated over the northern hemisphere (Horel and

489 Wallace, 1981) and the strengthened Aleutian low.

490 We thus calculated the correlations between the PC-1 and the WP index of the

491 Climate Prediction Center (Barnston and Livezey, 1987) as well as the North Pacific

492 Index (NPI). The NPI is an index of Aleutian low strength and is defined as the sea

493 level pressure averaged over a region from $30^{\circ}-60^{\circ} \mathrm{N}$ and $160^{\circ} \mathrm{E}-140^{\circ} \mathrm{W}$ (Trenberth 
and Hurrell, 1994). The significant negative correlation between the PC-1 and the WP index is obtained $(r=-0.46)$ at $90 \%$ confidence level, when we use the WP index in January. The PC-1 has a significant correlation with the NPI in December $(r=-0.60)$ at $95 \%$ confidence level. Thus, when the WP pattern is in the negative phase and the Aleutian low is strengthened, the sea level in and around the Sea of Okhotsk is piled up coherently, mainly associated with strengthened ATWs.

\section{Relation to sea ice extent variability}

It is known that the southward transport of the ESC has a role on the southward transport of the sea ice extent within the Sea of Okhotsk (Fukamachi et al., 2009). The current along Sakhalin Island associated with the coherent sea level pile-up may lead to the southward extension of the sea ice. Conversely, the current along the Kamchatka Peninsula associated with the sea level pile-up may suppress the sea ice extent through the inflow of warmer water from the Pacific. The importance of the ocean thermal condition in the East Kamchatka Current on the interannual variability of the sea ice extent in February to March has been suggested (Nakanowatari et al., 2010).

We now examine the relationship between the sea ice extent variability and the 
513 PC-1 of the sea level in winter, assuming that the ocean current affects the sea ice

514 extent. We use the sea ice concentration data from 1971 to 2006 provided from the

515 Japan Meteorological Agency (JMA). These data are a merged product from various

516 sources of observations, including visual and aircraft observations as well as satellite

517 observations of infrared, visible, and microwave radiometers.

518 Based on the correlation analysis between the monthly sea ice extent averaged

519 over the Sea of Okhotsk and the PC-1 (sea level during December to February) from

5201971 to 1988 , the PC-1 has by far the highest negative correlation with the sea ice

521 extent in January $(r=-0.67$, significant at $95 \%$ confidence level based on the Monte

522 Carlo simulation). As also shown in the time series (Fig. 12), less ice extent

523 corresponds well with larger PC-1 implying stronger currents. The PC-1 based on

524 the sea level data from December to January is still significantly correlated with the

525 sea ice extent in January $(r=-0.69)$. Conversely, the correlations between the PC-1 and

526 the sea ice extent in December and February are only -0.01 and -0.32 , respectively.

527 In December, the sea ice extent variability has been reported to be mostly

528 determined by the local heat flux over the northwestern area in the preceding autumn

529 (October-November) (Ohshima et al., 2006; Sasaki et al., 2007). In February to

530 March, the ocean thermal condition inflowing from the Pacific is also a determinant 
531 factor for the sea ice extent as well (Nakanowatari et al., 2010). Our result implies that

532 for January, the warmer coastal current from the Pacific, associated with the sea level

533 pile-up, suppresses the sea ice extent dynamically and/or thermodynamically.

534

535

536

\section{Summary and discussion}

537

538

The cause of the sea level variability in the Sea of Okhotsk had previously been

investigated mostly in terms of the relation to wind-driven ocean circulation (Ebuchi,

540 2006; Andreev and Shevchenko, 2008). Using satellite altimeter data, Ebuchi (2006)

541 indicated that the seasonal to interannual variability of the ESC is related to both the

542 ATWs caused by alongshore wind stress and the Sverdrup transport by wind stress

543 curl. However, these previous studies were based on altimeter data in no sea ice

544 seasons or tide gauge data only in the southern part of the Sea of Okhotsk. The sea

545 level variability over the entire Sea of Okhotsk for the full annual cycle had not yet

546 been examined. In this study, using tide gauge data in and around the Sea of Okhotsk

547 and satellite altimeter data, we examined the seasonal and interannual variations of the

548 sea level and their causes in terms of both the thermosteric signal and wind-driven

549 ocean circulation. 

to be dominated by the seasonal variation with a maximum in winter and a minimum in summer. Since this seasonal variation is not explained by the annual heat flux cycle and inverse barometer effect caused by changing atmospheric pressure, the cause for

554 the seasonal variation is explored in terms of the ATW and Sverdrup transports. We 555 found that both transports show the corresponding seasonal variation. The seasonal 556 amplitude of the sea level is relatively large along Sakhalin Island with a tendency of

557 larger amplitudes toward the south. This meridional dependence of the seasonal variation is consistent with the ATWs but not with the Sverdrup transport in the Sea of

559 Okhotsk. The seasonal amplitudes of the geostrophic current speed of the nearshore ESC and the associated volume transport estimated from the observed sea level data are $\sim 16 \mathrm{~cm} \mathrm{~s}^{-1}$ and $\sim 1.3 \mathrm{~Sv}$, respectively. These values are quantitatively comparable to the observed amplitude of the current speed $\left(\sim 20 \mathrm{~cm} \mathrm{~s}^{-1}\right)$ and the theoretical ATW transport $(\sim 1 \mathrm{~Sv})$. While the Sverdrup transport partly explains the seasonal sea level

564 variation, its contribution is smaller than that of the ATWs. 
568 first EOF mode of the wintertime sea level explains $61 \%$ of the total variance with a

569 large amplitude along Sakhalin Island. Satellite altimeter data support these results

570 and clearly reveal that the coherent sea level variation is trapped over the continental

571 shelf (Fig. 9b). Wintertime sea level along Sakhalin Island has a higher correlation

572 with the ATW transport than with the Sverdrup transport. On the other hand, the

573 significant correlation between the sea level along Sakhalin Island and the ATWs is

574 not found from spring to autumn. These findings imply that the interannual sea level

575 variation along the coastal and shelf regions in the Sea of Okhotsk in winter, as well

576 as the seasonal variation, is mainly caused by the ATWs (coastal trapped currents

577 forced by alongshore wind stress). The wintertime Sverdrup transport, raised by the

578 previous studies, seems to be a secondary factor.

579 The present study also showed that the sea levels along the upstream East

580 Kamchatka coast and the downstream Oyashio coast coherently vary with the sea

581 level around the Sea of Okhotsk on seasonal to interannual timescales and that these

582 variations have higher correlation with the ATWs than with the Sverdrup transports.

583 The importance of the wind stress along the coast on the sea level variability was

584 pointed out only by a numerical study (Tatebe and Yasuda, 2005). The present study

585 raises the caution about the previous studies that the coastal sea level variability is 
586

587

588

589

590

591

592

593

594

595

596

597

598

599

600

601

602

603

determined by the Sverdrup transport.

It is known that the ESC transport and its variability is mainly governed by the

Sverdrup transport (Ohshima et al., 2004; Simizu and Ohshima, 2006). Conversely,

this study suggests that the coastal sea level variability is primarily explained by the

ATWs. The ATWs have a shallow structure and are trapped over the nearshore region,

while the western boundary current exists offshore with a deeper structure. Therefore,

the coastal sea level can be largely governed by the ATWs, despite that the ATW

transport is one order less than the Sverdrup transport. Our results are consistent with

the previous numerical study (Shimada et al., 2005), which showed that the shelf

region has a role of an obstacle on the intrusion of the barotropic response in the

central basin. Since the northeasterly wind stress anomaly (Fig. 11a) is accompanied

by the strengthened wind stress curl in the Sea of Okhotsk, a part of the correlation

between the sea level and Sverdrup transport might be an apparent one.

Using an OGCM and analytical models, Tsujino et al. (2008) proposed that the

ATWs are responsible for the seasonal variations of the throughflow transport of the Japan Sea. Wintertime wind stress along the coastal region of the Sea of Okhotsk yields the positive SSHAs and the following SSH rise weakens the Tsushima Warm

Current as well as the Soya Warm Current in winter. Our result that the seasonal sea 
604 level variation in the Sea of Okhotsk is dominated by the ATWs supports their study.

605 We also found that the interannual variation of the coastal sea level in winter is well

606 explained by the ATWs. According to Ebuchi et al. (2009) and Fukamachi et al.

607 (2010), the Soya Warm Current exhibits interannual variability even in winter,

608 although the average transport is small in winter. Therefore, we would like to propose

609 that the ATWs (i.e., alongshore wind stress) partly control these throughflow

610 transports on an interannual timescale as well as seasonal timescale.

611 In this study, the ATWs are assumed to be barotropic for simplicity, on the basis

612 of Csanady (1978). Even if the effect of stratification is taken into account, our results

613 would not be essentially changed. Since the ATWs could have a partially baroclinic

614 structure analogous to the coastally trapped waves (CTWs) that have a hybrid

615 structure of barotropic shelf waves and internal Kelvin waves, it is likely that the

616 ATWs are somewhat accompanied by the dynamical displacement of isopycnals.

617 Actually, Mizuta et al. (2004) showed that the alongshore component of wind stress is

618 essential for the interannual variability of the isopycnals in the southern part of the

619 Sea of Okhotsk in winter. Considering that the subinertial variability of velocity in the

620 ESC over the continental shelf is dominated by CTWs and its vertical structure is

621 fairly barotropic (Mizuta et al., 2005), it is expected that the vertical structure of the 
622 ATWs in the Sea of Okhotsk is also fairly barotropic, while that the coherent sea level

623 variation is partly or slightly accompanied by the displacement of isopycnals.

624 Previous studies suggest that wintertime increases in the sea level along the

625 Okhotsk coast of Hokkaido (Itoh and Ohshima, 2000) and the Oyashio coast (Isoda et

626 al., 2003) are related to the advent of lighter ESC water from the upstream region. In

627 fact, sea surface salinity reductions are observed along Sakhalin Island $\left(\sim 50^{\circ} \mathrm{N}\right)$ in

628 autumn (Shevchenko and Chastikov, 2008). From the current velocity data of the

629 ESC, the Amur River discharge in May is estimated to arrive at the coast of Sakhalin

630 Island $\left(\sim 50^{\circ} \mathrm{N}\right)$ by October (Mizuta et al., 2003). When we carefully see Fig. 3b, it

631 seems that the tide gauge sea level near the Amur River (D) begin to rise in September

632 to October (Fig. 3b). Thus, a portion of the sea level rise along Sakhalin Island in

633 autumn-winter may be related to advection of low-salinity water from the Amur

634 River.

635 With respect to the interannual variability, we also examine the effect of the

636 advent of lighter ESC water from the upstream region on the sea level fluctuation

637 using the tide gauge data. The wintertime peak is commonly found in December along

638 Sakhalin Island (Fig. 6a) and the Okhotsk coast of Hokkaido (L, Fig. 3b). While, the

639 timing of the peak along the Oyashio coast in January is one month behind that along 
640 Sakhalin Island in December. Thus, we calculated the lead-lag correlations between

641 the monthly sea level anomalies among all these tide gauges during winter (from

642 November to March). Significant correlations are obtained only for no time lag, and

643 we could not find any significant correlations when the sea level along Sakhalin

644 Island leads those at the downstream stations by one or two months. Thus, the effect

645 of the advent of cold and fresh water is considered to be smaller than that of the

646 dynamical displacement in the southern part of the Sea of Okhotsk on the interannual

647 timescale.

648

649 Acknowledgments

650

651

Tide gauge data around the Sea of Okhotsk were provided by the Far Eastern

652

Regional Hydrometeorological Research Institute. Some figures were produced with

653 the GrADS package developed by B. Doty. The altimeter products were produced by

654 SSALTO/DUACS and distributed by AVISO with support from CNES. We wish to

655 thank N. Ebuchi for his constructive discussion and anonymous reviewers for their

656 constructive comments. This work was supported by a fund from Core Research for

657 Evolution Science and Technology (CREST), Japan Science and Technology 
658 Corporation (JST), Grant-in-Aid for Scientific Research (20221001, 22221001). 
659

660

661

662

663

664

665

666

667

668

669

670

671

672

673

674

675

676

677

678

679

680

681

682

\section{References}

Andreev, A.G., Shevchenko, G.V., 2008. Interannual variability of water transport by the East Kamchatka and East Sakhalin Currents and their influence on dissolved oxygen concentration in the Sea of Okhotsk and subarctic Pacific. Russian Meteorology and Hydrology, 33, 657-664 (in English).

Antonov, J.I., Locarnini, R.A., Boyer, T.P., Mishonov, A.V., Garcia, H.E., 2006. World Ocean Atlas 2005, vol.2, Salinity, NOAA Atlas NESDIS 62, 182 pp., NOAA, Silver Spring, Md.

Aota, M., 1975. Studies on the Soya Warm Current. Teion Kagaku, 33, 151-172 (in Japanese).

Barnston, A.G., Livezey, R. E., 1987. Classification, seasonality and persistence of low-frequency atmospheric circulation patterns. Monthly Weather Review, 115, 1083-1126.

Csanady, G.T., 1978. The arrested topography wave. Journal of Physical Oceanography, 8, 47-62.

Dai, A., Trenberth, K.E., 2002. Estimates of freshwater discharge from continents: Latitudinal and seasonal variations. Journal of Hydrometeorology, 3, 660-687.

Ducet, N., Le Traon, P.Y., Reverdin, G., 2000. Global high-resolution mapping of ocean circulation from TOPEX/Poseidon and ERS-1 and -2. Journal of Geophysical Research, 105, 19,477-19,498.

Ebuchi, N., 2006, Seasonal and interannual variations in the East Sakhalin Current revealed by TOPEX/POSEIDON altimeter data. Journal of Oceanography, 62, $171-183$. 
683

684

685

686

687

688

689

690

691

692

693

694

695

696

697

698

699

700

701

Ebuchi, N., Fukamachi, Y., Ohshima, K.I., Shirasawa, K., Ishikawa, M., Takatsuka, T., Daibo, T., Wakatsuchi, M., 2006. Observation of the Soya Warm Current using HF ocean radar. Journal of Oceanography, 61, 47-61.

Ebuchi, N., Fukamachi, Y., Ohshima, K. I., Wakatsuchi, M., 2009. Subinertial and seasonal variations in the Soya Warm Current revealed by HF ocean radars, coastal tide gauges, and bottom-mounted ADCP. Journal of Oceanography, 65, 31-43.

Fukamachi, Y., Shirasawa, K., Polomoshnov, A.M., Ohshima, K.I., Kalinin, E., Nihashi, S., Melling, H., Mizuta, G., Wakatsuchi, M., 2009. Direct observations of sea-ice thickness and brine rejection off Sakhalin in the Sea of Okhotsk. Continental Shelf Research, 29, 1541-1548.

Fukamachi, Y., Ohshima, K. I., Ebuchi, N., Bando, T., Ono, K., Sano, M., 2010. Volume transport in the Soya Strait during 2006-2008. Journal of Oceanography, $66,685-696$.

Gill, A.E., Niiler, P.P., 1973. The theory of the seasonal variability in the ocean. Deep Sea Research, 20, 141-177.

Godfrey, J.S., 1989. A Sverdrup model of the depth-integrated flow for the world ocean allowing for island circulations. Geophysical and Astrophysical Fluid Dynamics, 45, 89-112.

Horel, J.D., Wallace, J.M., 1981. Planetary-scale atmospheric phenomena associated with the Southern Oscillation. Monthly Weather Review, 109, 813-829.

Isoguchi, O., Kawamura, H., Kono, T., 1997. A study on wind-driven circulation in the subarctic North Pacific using TOPEX/POSEIDON altimeter data. Journal of Geophysical Research, 102, 12,457-12,468. 
Isoguchi, O., Kawamura, H., 2006. Seasonal to interannual variations of the western boundary current of the subarctic North Pacific by a combination of the altimeter and tide gauge sea levels. Journal of Geophysical Research, 111, C04013, doi:10.1029/2005JC003080.

Isoda, Y., Kuroda, H., Myousyo, T., Honda, S., 2003. Hydrographic feature of coastal Oyashio and its seasonal variation. Bulletin on Coastal Oceanography, 41, 5-12 (in Japanese with English abstract).

Ito, S., Uehara, K., Miyao, T., Miyake, H., Yasuda, I., Watanabe, T., Shimizu, Y., 2004. Characteristics of SSH anomaly based on TOPEX/POSEIDON altimeter and in situ measured velocity and transport of Oyashio on OICE. Journal of Oceanography, 60, 425-437.

Itoh, M., Ohshima, K.I., 2000. Seasonal variations of water masses and sea level in the southwestern part of the Okhotsk Sea. Journal of Oceanography, 56, 643-654.

Kalnay, E., Kanamitsu, M., Kistler, R., Collins, W., Deaven, D., Gandin, L., Iredell, M., Saha, S., White, G., Woollen, J., Zhu, Y.,Leetmaa, A., Reynolds, B., Chelliah, M., Ebisuzaki, W., Higgins, W., Janowiak, J., Mo, K.C., Ropelewski, C., Wang, J., Jenne, R., Joseph, D., 1996. The NCEP/NCAR 40-year reanalysis project. Bulletin of the American Meteorological Society, 77, 437-471.

Kanamitsu, M., 1989. Description of the NMC global data assimilation and forecast system. Weather and Forecasting, 4, 335-342.

Kaplan, D., Glass, L., 1995. Understanding nonlinear dynamics. Springer-Verlag, pp. 420.

Katsumata, K., Yasuda, I., 2010. Estimates of non-tidal exchange transport between the Sea of Okhotsk and the North Pacific. Journal of Oceanography, 66, 489-504. 
731

732

733

734

735

736

737

738

739

740

741

742

Konishi, T., Kamie, E., Segawa, T., 1986. Characteristics of tides along the coast of Japan. Kaiyo Kagaku, 18, 437-441 (in Japanese).

Large, W.G., Pond, S., 1981. Open ocean momentum flux measurements in moderate to strong winds. Journal of Physical Oceanography, 11, 324-336.

Leppäranta, M., 2005. The drift of sea ice. Springer, Berlin.

Leonov, A.K., 1960. The Sea of Okhotsk, National Technical Information Service, Springfield, VA, U. S. A.

Locarnini, R.A., Mishonov, A.V., Antonov, J.I., Boyer, T.P., Garcia, H.E., 2006. World Ocean Atlas 2005, vol. 1: Temperature, NOAA Atlas NESDIS 61, 182 pp., NOAA, Silver Spring, Md.

Lockridge, P.A., 1995. NGDC monitors frequency of recent destructive tsunami events. Earth System Monitor, 5, 1-12.

Masumoto, Y., Sasaki, H., Kagimoto, T., Komori, N., Ishida, A., Sasai, Y., Miyama, T., Motoi, T., Mitsudera, H., Takahashi, K., Sakuma, H., Yamagata, T., 2004. A fifty-year eddy-resolving simulation for the World Ocean-Preliminary outcomes of OFES (OGCM for the Earth Simulator)-. Journal of the Earth Simulator, 1, $35-56$.

Matsuyama, M., Wadaka, M., Abe, T., Aota, M., Koike, Y., 2006. Current structure and volume transport of the Soya Warm Current in summer. Journal of Oceanography, 62, 197-205.

Mizuta, G., Fukamachi, Y., Ohshima, K.I., Wakatsuchi. M., 2003. Structure and seasonal variability of the East Sakhalin Current. Journal of Physical Oceanography, 33, 2430-2445.

Mizuta, G., Ohshima, K.I., Fukamachi, Y., Itoh, M., Wakatsuchi, M., 2004. Winter 
mixed layer and its yearly variability under sea ice in the southwestern part of the Sea of Okhotsk. Continental Shelf Research, 24, 643-657.

Mizuta, G., Ohshima, K.I., Fukamachi, Y., Wakatsuchi, M., 2005. The variability of the East Sakhalin Current induced by winds over the continental shelf and slope. Journal of Marine Research, 63, 1017-1039.

Morimoto, A., 2009. Evaluation of tidal error in altimetry data in the Asian marginal seas. Journal of Oceanography, 65, 477-485.

Nakanowatari, T., Ohshima, K.I., Nagai, S., 2010. What determines the maximum sea ice extent in the Sea of Okhotsk? Importance of ocean thermal condition from the Pacific. Journal of Geophysical Research, 115, C12031, doi:10.1029/2009JC006070.

Nishioka, J., Ono, T., Saito, H., Nakatsuka, T., Takeda, S., Yoshimura, T., Suzuki, K., Kuma, K., Nakabayashi, S., Tsumune, D., Mitsudera, H., Johnson, W.K., Tsuda, A., 2007. Iron supply to the western subarctic Pacific: Importance of iron export from the Sea of Okhotsk. Journal of Geophysical Research, 112, C10012, doi:10.1029/2006JC004055.

Ohshima, K.I., 1994. The flow system in the Japan Sea caused by a sea-level difference through shallow straits. Journal of Geophysical Research, 99, C5, 9925-9940.

Ohshima, K.I., Wakatsuchi, M., Fukamachi, Y., Mizuta, G., 2002. Near-surface circulation and tidal currents of the Okhotsk Sea observed with satellite-tracked drifters. Journal of Geophysical Research, 107, 3195, doi:10.1029/2001JC001005.

Ohshima, K.I., Simizu, D., Itoh, M., Mizuta, G., Fukamachi, Y., Riser, S.C., 
Wakatsuchi, M., 2004. Sverdrup balance and the cyclonic gyre in the Sea of Okhotsk, Journal of Physical Oceanography, 34, 513-525.

Ohshima K.I., Riser, S.C., Wakatsuchi, M., 2005. Mixed layer evolution in the Sea of Okhotsk observed with profiling floats and its relation to sea ice formation. Geophysical Research Letter, 32, L06607, doi:10.1029/2004GL021823.

Ohshima, K.I., Nihashi, S., Hashiya, E., Watanabe T., 2006. Interannual variability of sea ice area in the Sea of Okhotsk: importance surface heat flux in fall. Journal of Meteorological Society of Japan, 84, 907-919.

Ohshima, K. I., Simizu, D., 2008. Particle tracking experiments on a model of the Okhotsk Sea: Toward oil spill simulation, Journal of Oceanography, 64, 103-114.

Ohshima, K.I., Nakanowatari, T., Riser, S.C., Wakatsuchi M., 2010. Seasonal variation in the in- and outflow of the Okhotsk Sea with the North Pacific, Deep Sea Research Part II, 57, 1247-1256.

Qiu, B., 2002. Large-scale variability in the midlatitude subtropical and subpolar North Pacific Ocean: Observations and causes. Journal of Physical Oceanography, 32, 353-375.

Sadaeva, O., Shevchenko, G., 2001. Investigation of seasonal fluctuations of sea level and atmospheric pressure in the area of Kuril ridge. Proceedings of the 16th international symposium on Okhotsk Sea and Sea Ice, Okhotsk Sea and cold Ocean Research Association, Japan, 339-342.

Sakamoto, K., Tsujino H., Nishikawa S., Nakano H., Motoi T., 2010. Dynamics of the Coastal Oyashio and Its Seasonal Variation in a High-Resolution Western North Pacific Ocean Model. Journal of Physical Oceanography, 40, 1283-1301.

Sasaki Y.N., Katagiri, Y., Minobe, S., Rigor, I.G., 2007. Autumn atmospheric 
803

804

805

806

807

808

809

810

811

812

813

814

815

816

817

818

819

820

821

822

823

824

825

826

preconditioning for interannual variability of wintertime sea-ice in the Okhotsk Sea. Journal of Oceanography, 63, 255-265.

Shcherbina, A.Y., Talley, L.D., Rudnick, D.L., 2004. Dense water formation on the northwestern shelf of the Okhotsk Sea: 2. Quantifying the transports. Journal of Geophysical Research, 109, C09S09, doi:10.1029/2003JC002197.

Shevchenko, G., Romanov, A., 2005. Seasonal variations of surface circulation in the Okhotsk Sea from Topex/Poseidon satellite altimetry data. Proceedings of the 20th international symposium on Okhotsk Sea and Sea Ice, Okhotsk Sea and cold Ocean Research Association, Japan, 295-302.

Shevhenko, G. V., Chastikov, V. N., 2008. Seasonal variations of oceanic conditions near the southeastern coast of Sakhalin Island. Russian Meteorology and Hydrology, 33, 514-524 (in English).

Schlax, M.G. Chelton, D.B., 1994. Aliased tidal errors in TOPEX/POSEIDON sea surface height data. Journal of Geophysical Research, 99, C8, 24761-24775.

Shimada, Y., Kubokawa, A., Ohshima, K.I., 2005. Influence of current width variation on the annual mean transport of the East Sakhalin Current: A simple model. Journal of Oceanography, 61, 913-920.

Simizu, D., Ohshima, K.I., 2002. Barotropic response of the Sea of Okhotsk to wind forcing. Journal of Oceanography, 58, 851-860.

Simizu, D., Ohshima, K.I., 2006. A model simulation on the circulation in the Sea of Okhotsk and the East Sakhalin Current. Journal of Geophysical Research, 111, C05016, doi:10.1029/2005JC002980.

Stammer, D., 1997. Steric and wind-induced changes in TOPEX/POSEIDON large-scale sea surface topography observations. Journal of Geophysical 
Research, 102, C9, 20,987-21,009.

828

829

830

831

832

Talley, L.D., Nagata, Y., 1995. The Okhotsk Sea and Oyashio Region. PICES Scientific Report, PICES, Sydney, B. C., Canada, 2, 227 pp.

Tatebe, H, Yasuda, I., 2005. Numerical experiments on the seasonal variations of the Oyashio near the east coast of Japan. Journal of Physical Oceanography, 35, 2309-2326.

Trenberth, K.E., Hurrell, J.W., 1994. Decadal atmosphere-ocean variations in the Pacific. Climate Dynamics, 9, 303-319.

Tsujino, H., Nakano, H., Motoi T., 2008. Mechanism of currents through the straits of the Japan Sea: Mean state and seasonal variation. Journal of Oceanography, 64, $141-161$.

Uchimoto, K., Mitsudera, H., Ebuchi, N., Mizuta, G., 2008. Seasonal variations of the sea level in the eastern part of the Kuril Basin. Umi to Sora, 84, 93-99 (in Japanese with English abstract and figure captions).

Uppala, S.M., Kallberg, P.W., Simmons, A.J., Andrae, U., Da Costa Bechtold, V., Fiorino, M., Gibson, J.K., Haseler, J., Hernandez, A., Kelly, G.A., Li, X., Onogi, K., Saarinen, S., Sokka, N., Allan, R.P., Andersson, E., Arpe, K., Balmaseda, M.A., Beljaars, A.C.M., van de Berg, L., Bidlot, J., Bormann, N., Caires, S., Chevallier, F., Dethof, A., Dragosavac, M., Fisher, M., Fuentes, M., Hagemann, S., Ho' lm, E., Hoskins, B.J., Isaksen, L., Janssen, P.A.E.M., Jenne, R., McNally, A.P., Mahfouf, J.-F., Morcrette, J.-J., Rayner, N.A., Saunders, R.W., Simon, P., Sterl, A., Trenberth, K.E., Untch, A., Vasiljevic, D., Viterbo, P., Woollen, J., 2005. The ERA-40 re-analysis. Quarterly Journal of the Royal Meteorological Society $131,2961-3012$. 
851 Vivier, F., Kelly K. A., Thompson L., 1999. Contributions of wind forcing, waves, and 852 surface heating to sea surface height observations in the Pacific Ocean. Journal $853 \quad$ of Geophysical Research, 104, 20,767-20,788.

854 Woodworth, P.L., 1991. The permanent service for mean sea level and the global sea 855 level observing system. Journal of Coastal Research, 7, 699-710. 856 
857

858

859

860

861

862

863

864

865

866

867

868

869

870

871

872

873

874

875

876

877

878

879

880

881

\section{Figure captions}

Fig. 1. Bathymetry map of the Sea of Okhotsk with the positions of the tide gauge stations used in this study. Filled and open circles indicate the tide gauge stations at which the available data length before 1994 is longer and shorter than 25 years, respectively. The station names from A to $\mathrm{O}$ are listed in Table 1 . The bathymetry data are derived from the ETOPO5. The contour levels are 100-, 500-, 1000-, and 2000-m depths.

Fig. 2. Time series of monthly sea level (black line) averaged over the tide gauge stations along Sakhalin Island (E, G, H, I, J; see Fig. 1 for locations of the tide gauges) and ATW transport (gray line) for route 1 (see Fig. 5c for the route) from 1965 to 1975. The sea level and ATW transport are shown by the anomalies from the averages for the whole period.

Fig. 3. (a) Monthly mean climatologies of the sea level from the tide gauge data (see Fig. 1 for the locations of the tide gauges). (b) Same as (a), but the thermosteric components related to surface heat flux and the inverse barometer effect caused by atmospheric pressure are removed. Black, red, and blue lines indicate the tide gauge data for the northern part of the Sea of Okhotsk including the Kamchatka Peninsula, Sakhalin Island, and the coastal region of Hokkaido Island, respectively.

Fig. 4. Climatological sea level difference $(\mathrm{cm})$ between December and May for (a) the tide gauge data (see Fig. 1 for the locations of the tide gauges) and (b) the satellite altimeter data. In (b), regions in which the sea ice concentration is larger than $10 \%$ are 
masked out by white color.

Fig. 5. (a) Wind stress (vectors; $\mathrm{N} / \mathrm{m}^{2}$ ) and sea level pressure (contours; hPa) from ERA-40 data for the period 1958-2001 in winter (December to February). The contour interval is $5 \mathrm{hPa}$. The scale for the vectors is indicated at the bottom. (b) The Sverdrup transport streamfunction in winter. The Sverdrup transport in the Sea of Okhotsk and the North Pacific are calculated independently. The assumed eastern boundary for the Sea of Okhotsk is shown as a bold line. The contour intervals are 2 $\mathrm{Sv}$ and $10 \mathrm{~Sv}$ in the Sea of Okhotsk and the North Pacific, respectively. (c) The integral routes for the ATW transport. In (c), the integral routes 1, 2, and 3 are defined as the line from the corresponding starting points to the end point each marked with an open circle. The label of S, P, K indicates the Sakhalin, Petropavlovsk-Kamchatsky, and Kushiro stations, respectively.

Fig. 6. (a) The monthly mean climatologies of the tide gauge sea level averaged along Sakhalin Island (D-J). (b) The monthly mean climatologies of the ATW transport integrated over routes 1 (circle), 2 (triangle), and 3 (cross). The scale of the ATW transport for route 1 and 2 (3) is indicated on the left (right) axis. (c) The monthly mean climatologies of the Sverdrup transport over the Sea of Okhotsk (circle) and North Pacific (triangle). The scale for the Sverdrup transport in the Sea of Okhotsk (North Pacific) is indicated on the left (right) axis.

Fig. 7. Longitudinal dependence of the differences in the sea level, ATW transport, and Sverdrup transport between December and May. (a) Tide gauge data along the 
906

907

908

909

910

911

912

913

914

915

916

917

918

919

920

921

922

923

924

925

926

927

928

929

Sakhalin coast (station labels are indicated at the top). (b) ATW transport integrated from the starting point of route 1 to the corresponding latitude at the Sakhalin coast. (c) Sverdrup transport integrated over the Sea of Okhotsk (circle) and the North Pacific (triangle). In (c), the scale for the Sverdrup transport in the Sea of Okhotsk (North Pacific) is indicated on the left (right) axis.

Fig. 8. Time series of the sea level anomalies $(\mathrm{cm})$ at the tide gauge stations in winter (December to February) (see Fig. 1 for the locations of the tide gauges) and the temporal coefficients of the first EOF mode from the 11 tide gauge data in winter. Note that the sea level anomalies for each station are successively offset by $15 \mathrm{~cm}$.

Fig. 9. (a) Regression maps (colors) of the sea level anomalies onto the PC1 of the tide gauge sea levels in winter (December-February). (b) Regression maps (colors) of the December SSHAs onto the normalized SSHAs averaged over the area offshore of Sakhalin Island $\left(48-49^{\circ} \mathrm{N}, 143-144^{\circ} \mathrm{E}\right.$; indicated as green square). Contours indicate the areas where the correlation exceeds the $95 \%$ confidence level. The regions in which the sea ice concentration is larger than $10 \%$ are masked out by white.

Fig. 10. Time series of the wintertime (December to February) sea level anomalies (solid line) averaged along Sakhalin Island (E, G, H, I, J) (see Fig. 1 for the locations) and the ATW transport anomalies (dashed line) for route 1 (see Fig. 5c for the route location).

Fig. 11. Regression maps of (a) the wind stress, (b) wind stress curl, and (c) sea level 
930 pressure onto the PC-1 of the sea levels in winter (December to February). In (a), the 931 standard vector length of $0.03 \mathrm{~N} / \mathrm{m}^{2}$ is shown at the bottom. The contour intervals in 932 (b) and (c) are $0.2 \mathrm{~N} / \mathrm{m}^{3}$ and $0.5 \mathrm{hPa}$, respectively. Light (heavy) shading indicates the 933 region in which the positive (negative) correlation is significant at the $95 \%$ confidence 934 level.

935

936 Fig. 12. The time series of the PC-1 (solid line) of the wintertime (December to 937 February) sea levels and the sea ice extent anomalies in January (dashed line).

938 
Table 1

940 Locations of the tide gauge stations and the available data period

\begin{tabular}{|c|c|c|c|c|}
\hline Station Label & Station Name & Latitude & Longitude & Data Period \\
\hline $\mathrm{A}$ & Petropavlovsk-Kamchatsky $^{a}$ & $52^{\circ} 59^{\prime} \mathrm{N}$ & $158^{\circ} 39^{\prime} \mathrm{E}$ & $1958-2009$ \\
\hline B & Nagaevo & $59^{\circ} 33^{\prime} \mathrm{N}$ & $150^{\circ} 43^{\prime} \mathrm{E}$ & $1957-1993$ \\
\hline $\mathrm{C}$ & Okhotsk & $59^{\circ} 22^{\prime} \mathrm{N}$ & $143^{\circ} 12^{\prime} \mathrm{E}$ & $1972-1993$ \\
\hline $\mathrm{D}$ & Nabil & $51^{\circ} 44^{\prime} \mathrm{N}$ & $143^{\circ} 18^{\prime} \mathrm{E}$ & $1960-1964$ \\
\hline $\mathrm{E}$ & Poronaisk & $49^{\circ} 14^{\prime} \mathrm{N}$ & $143^{\circ} 08^{\prime} \mathrm{E}$ & $1950-1993$ \\
\hline $\mathrm{F}$ & Vostochniy & $48^{\circ} 17^{\prime} \mathrm{N}$ & $142^{\circ} 35^{\prime} \mathrm{E}$ & $1948-1957$ \\
\hline G & Vzmorie & $47^{\circ} 52^{\prime} \mathrm{N}$ & $142^{\circ} 29^{\prime} \mathrm{E}$ & $1950-1988$ \\
\hline $\mathrm{H}$ & Starodubskoe & $47^{\circ} 25^{\prime} \mathrm{N}$ & $142^{\circ} 49^{\prime} \mathrm{E}$ & $1950-1993$ \\
\hline $\mathrm{I}$ & Korsakov & $46^{\circ} 39^{\prime} \mathrm{N}$ & $142^{\circ} 45^{\prime} \mathrm{E}$ & 1948-1992 \\
\hline $\mathrm{J}$ & Krilion & $45^{\circ} 54^{\prime} \mathrm{N}$ & $142^{\circ} 05^{\prime} \mathrm{E}$ & $1961-1988$ \\
\hline $\mathrm{K}$ & Wakkanai $^{\mathrm{a}}$ & $45^{\circ} 24^{\prime} \mathrm{N}$ & $141^{\circ} 41^{\prime} \mathrm{E}$ & $1975-2009$ \\
\hline $\mathrm{L}$ & Monbetsu $^{\mathrm{a}}$ & $44^{\circ} 21^{\prime} \mathrm{N}$ & $143^{\circ} 22^{\prime} \mathrm{E}$ & $1956-2008$ \\
\hline $\mathrm{M}$ & Abashiri $^{\mathrm{a}}$ & $44^{\circ} 01^{\prime} \mathrm{N}$ & $144^{\circ} 17^{\prime} \mathrm{E}$ & 1965-2009 \\
\hline $\mathrm{N}$ & Kurilsk & $45^{\circ} 16^{\prime} \mathrm{N}$ & $147^{\circ} 53^{\prime} \mathrm{E}$ & 1951-1993 \\
\hline $\mathrm{O}$ & Kushiro $^{a}$ & $42^{\circ} 58^{\prime} \mathrm{N}$ & $144^{\circ} 22^{\prime} \mathrm{E}$ & $1947-2009$ \\
\hline
\end{tabular}

$941{ }^{a}$ Data from the PSMSL.

942

943 
Table 2

945 Correlation coefficients between the sea level along Sakhalin Island and the Sverdrup 946 transport integrated over the Sea of Okhotsk (OK) and North Pacific (NP) and the 947 ATW transport integrated along routes 1,2 , and 3 (ATW-1, -2 , and -3 ), calculated 948 using ERA-40 and NCEP/NCAR reanalysis data in winter (December to February)

\begin{tabular}{|c|c|c|c|c|c|}
\hline & OK & NP & ATW-1 & ATW-2 & ATW-3 \\
\hline ERA40 & $\mathbf{0 . 6 4}$ & $\mathbf{0 . 3 7}$ & $\mathbf{0 . 6 6}$ & $\mathbf{0 . 5 3}$ & $\mathbf{0 . 6 2}$ \\
\hline NCEP-NCAR & $\mathbf{0 . 7 1}$ & 0.34 & $\mathbf{0 . 7 1}$ & $\mathbf{0 . 6 8}$ & $\mathbf{0 . 6 9}$ \\
\hline
\end{tabular}

949 Bold numbers indicate correlations exceeding the $95 \%$ confidence level based on the

950 Monte Carlo simulation, using a phase randomization technique generating 1,000

951 surrogate time series (Kaplan and Glass, 1995).

952

953 


\section{$954 \quad$ Table 3}

955 Correlation coefficients between the sea level along Sakhalin Island and ATW

956 transport for routes 1 and 3 in winter (December to February), spring (March to May),

957 summer (June to August), and autumn (September to November)

\begin{tabular}{|c|c|c|c|c|}
\hline & Winter & Spring & Summer & Autumn \\
\hline ATW-1 & $\mathbf{0 . 6 6}$ & 0.25 & $\underline{-0.07}$ & 0.42 \\
\hline ATW-3 & $\mathbf{0 . 6 2}$ & 0.03 & -0.17 & -0.01 \\
\hline
\end{tabular}

958 Bold numbers indicate the correlation exceeding the $95 \%$ confidence level.

959

960 
961

962

963

964 and Sverdrup transport in the North Pacific in winter (December to February)

\begin{tabular}{|c|c|c|}
\hline & ATW & Sverdrup transport \\
\hline PK & 0.65 & $0.59\left(\right.$ at $\left.51^{\circ} \mathrm{N}\right)$ \\
\hline Kushiro & 0.59 & $0.56\left(\right.$ at $\left.42^{\circ} \mathrm{N}\right)$ \\
\hline
\end{tabular}

965 Bold numbers indicate the correlations exceeding the $95 \%$ confidence level. 


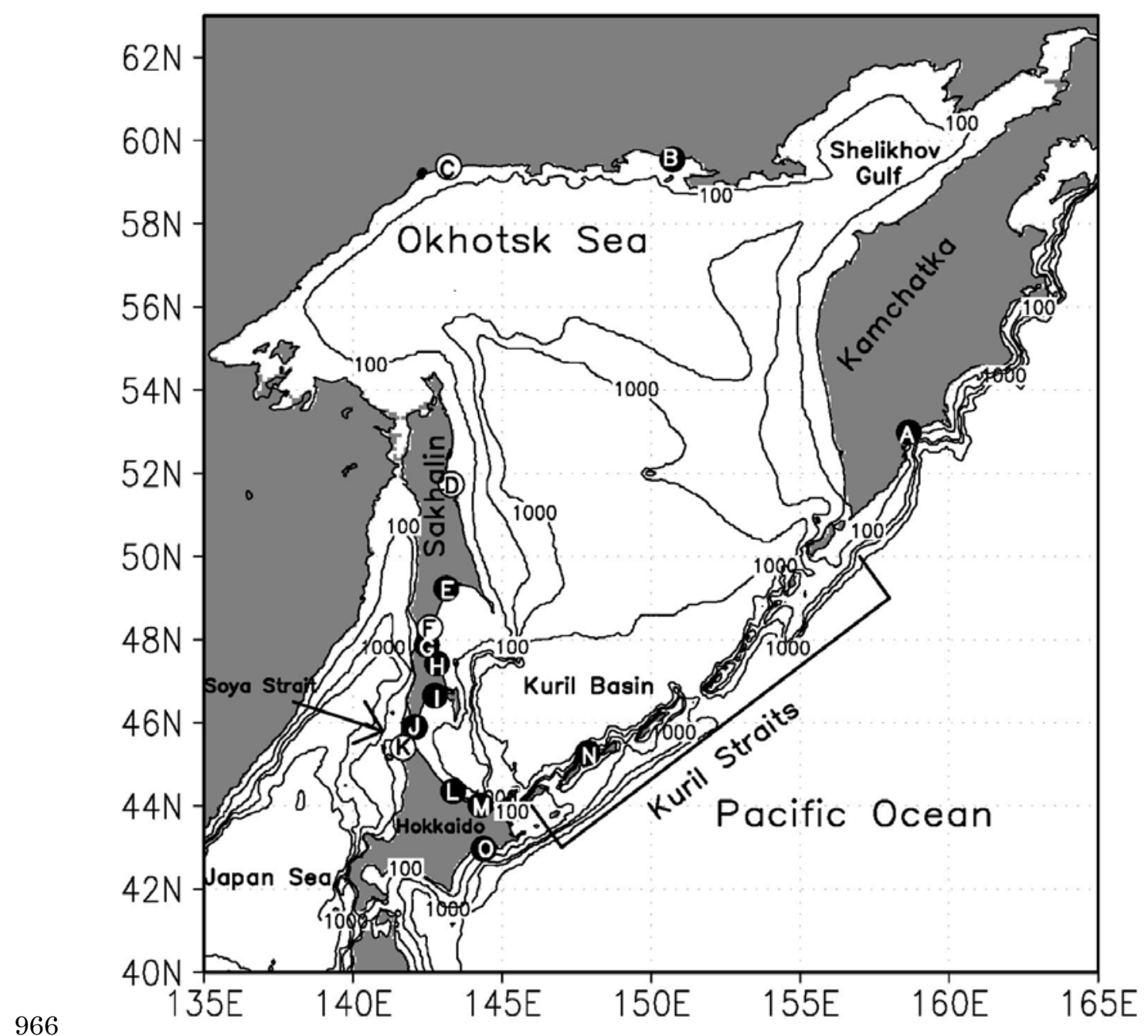

Figure 1. 


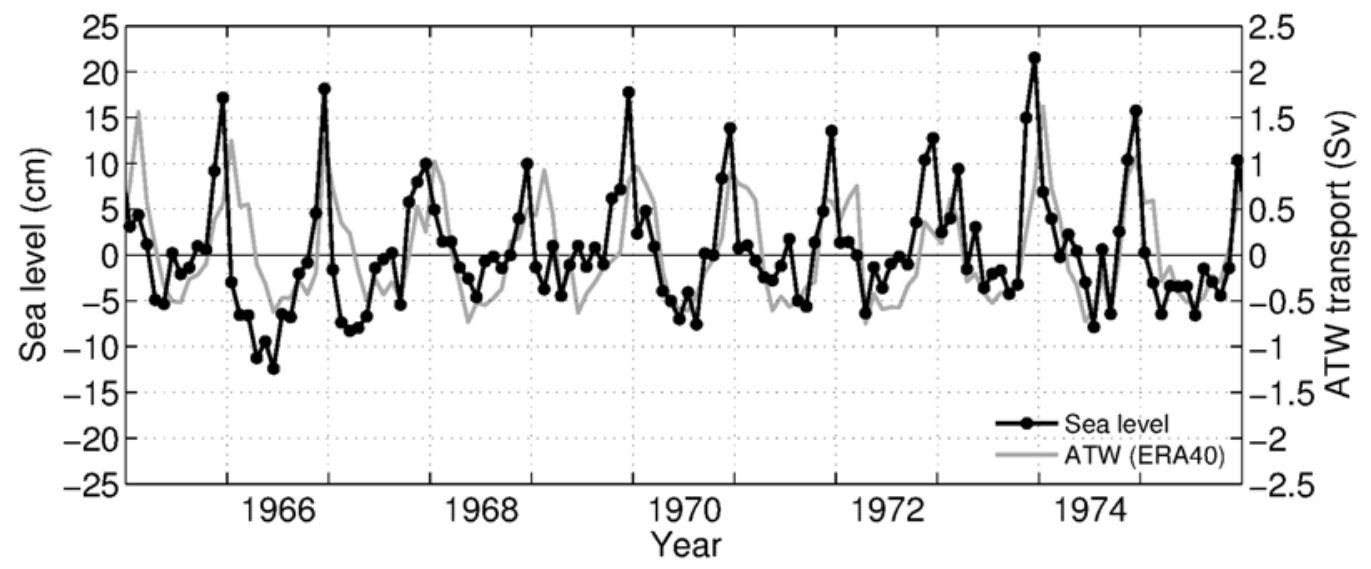

969

970

Figure 2. 

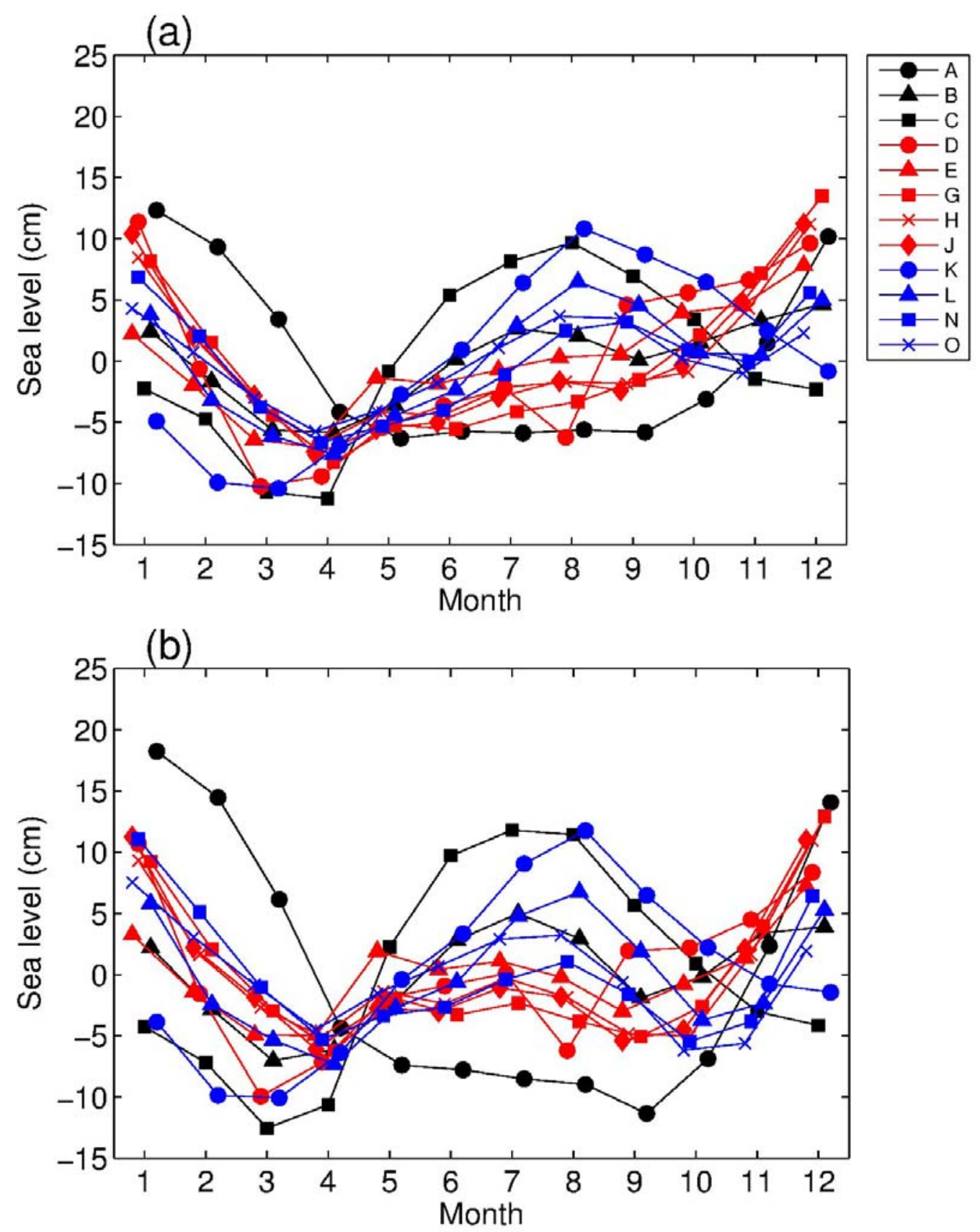

971

$972 \quad$ Figure 3. 

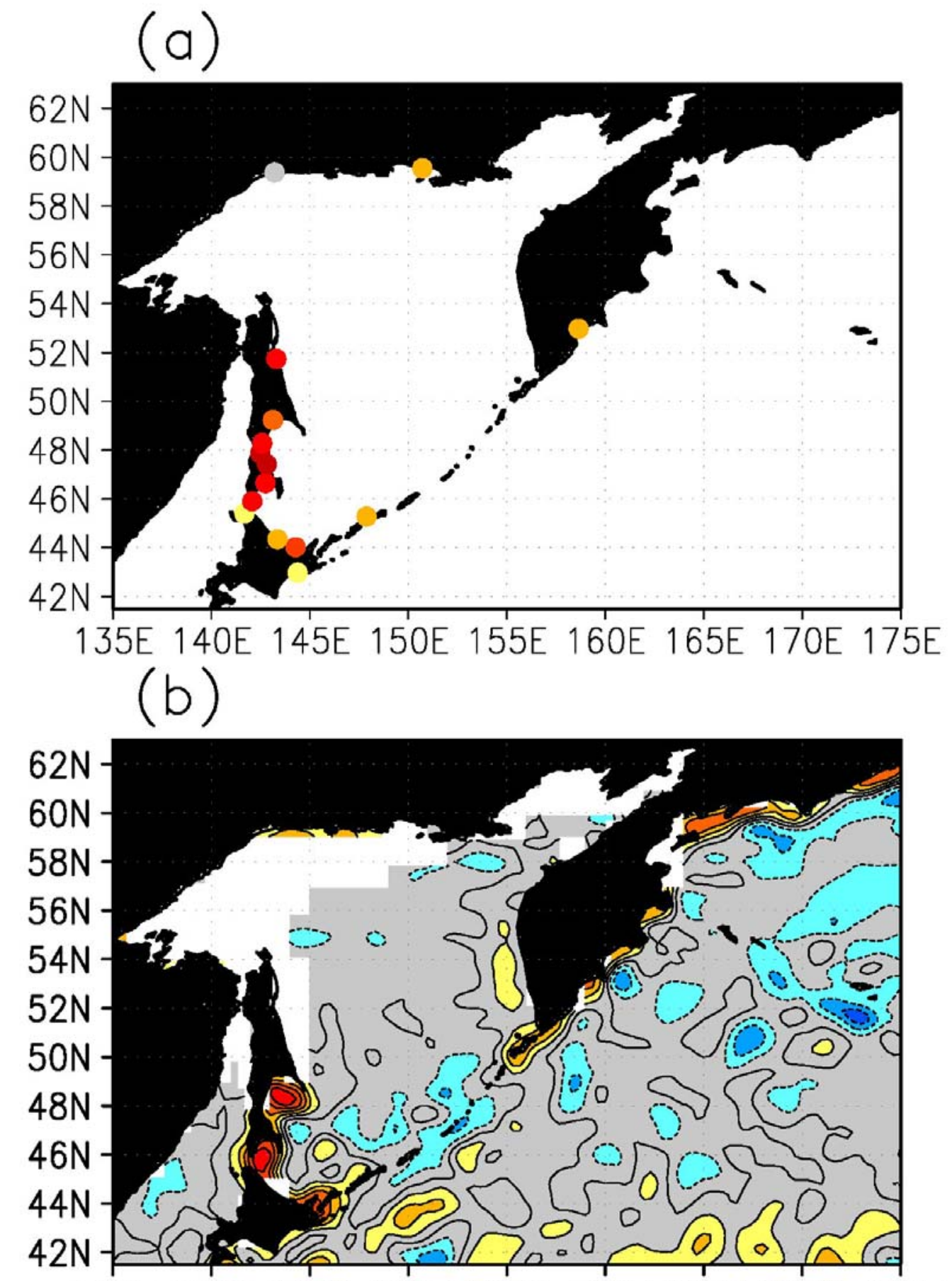

135E 140E 145E 150E 155E 160E 165E 170E 175E

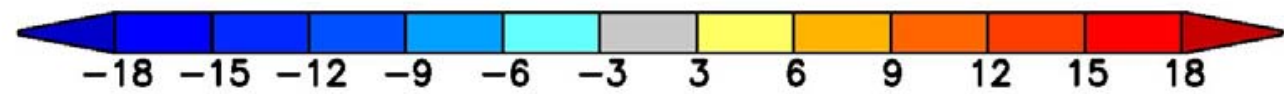

$974 \quad$ Figure 4. 

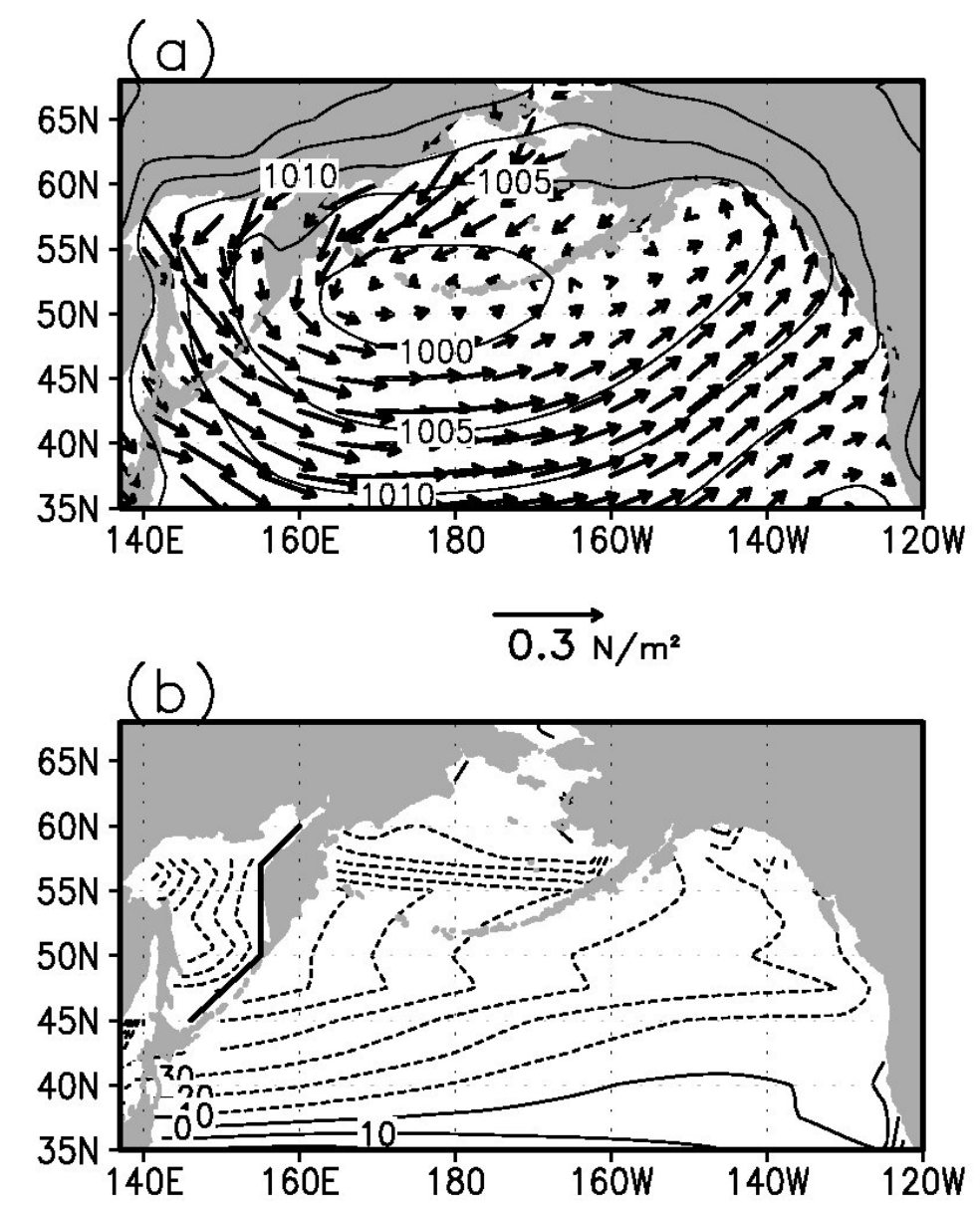

975

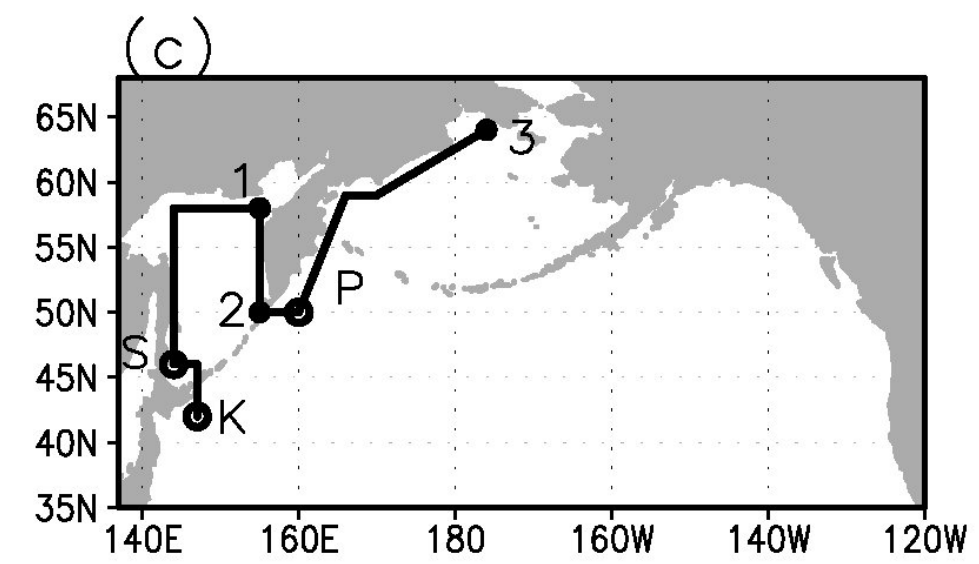

$976 \quad$ Figure 5.

977

978 

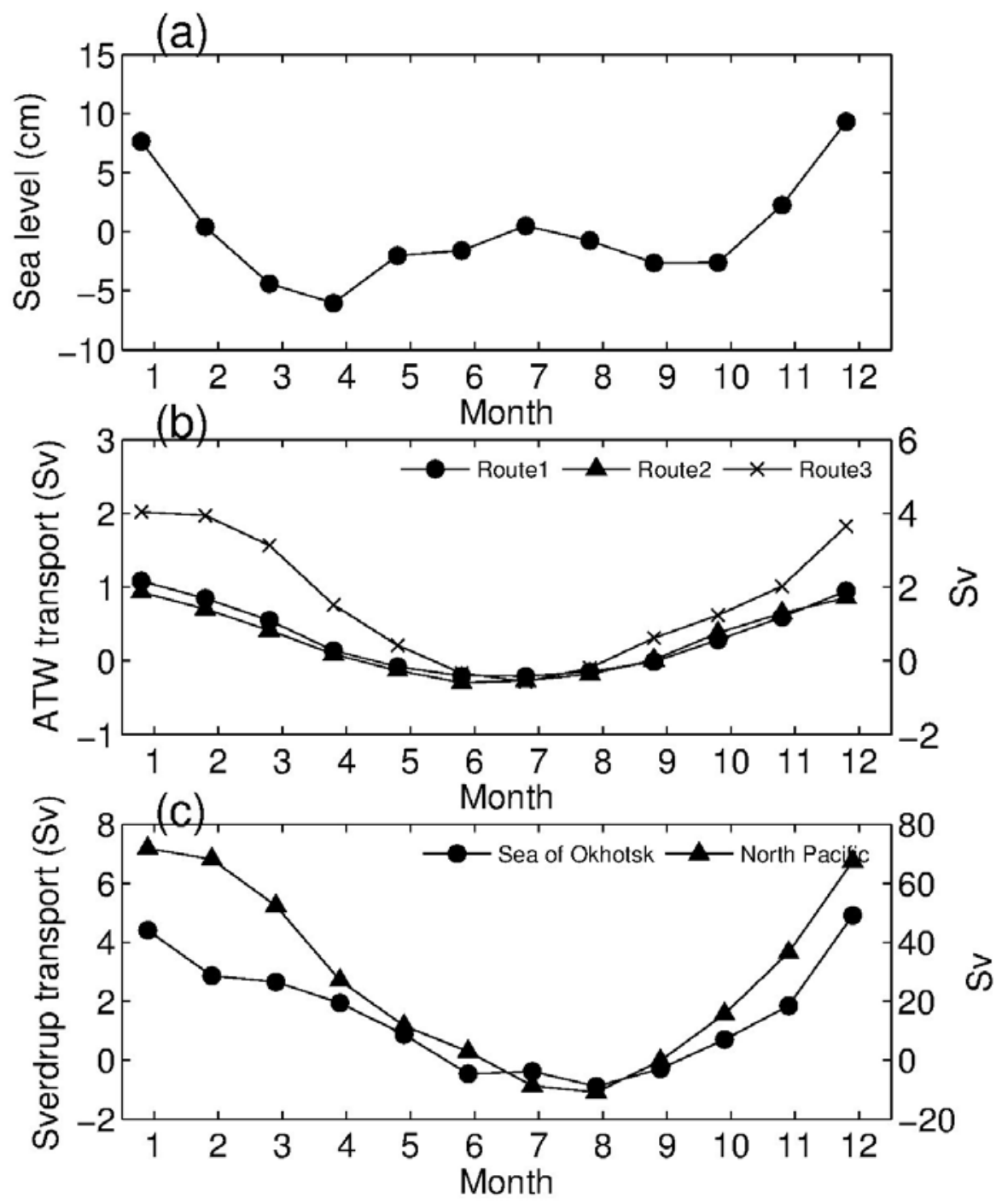

979

$980 \quad$ Figure 6. 

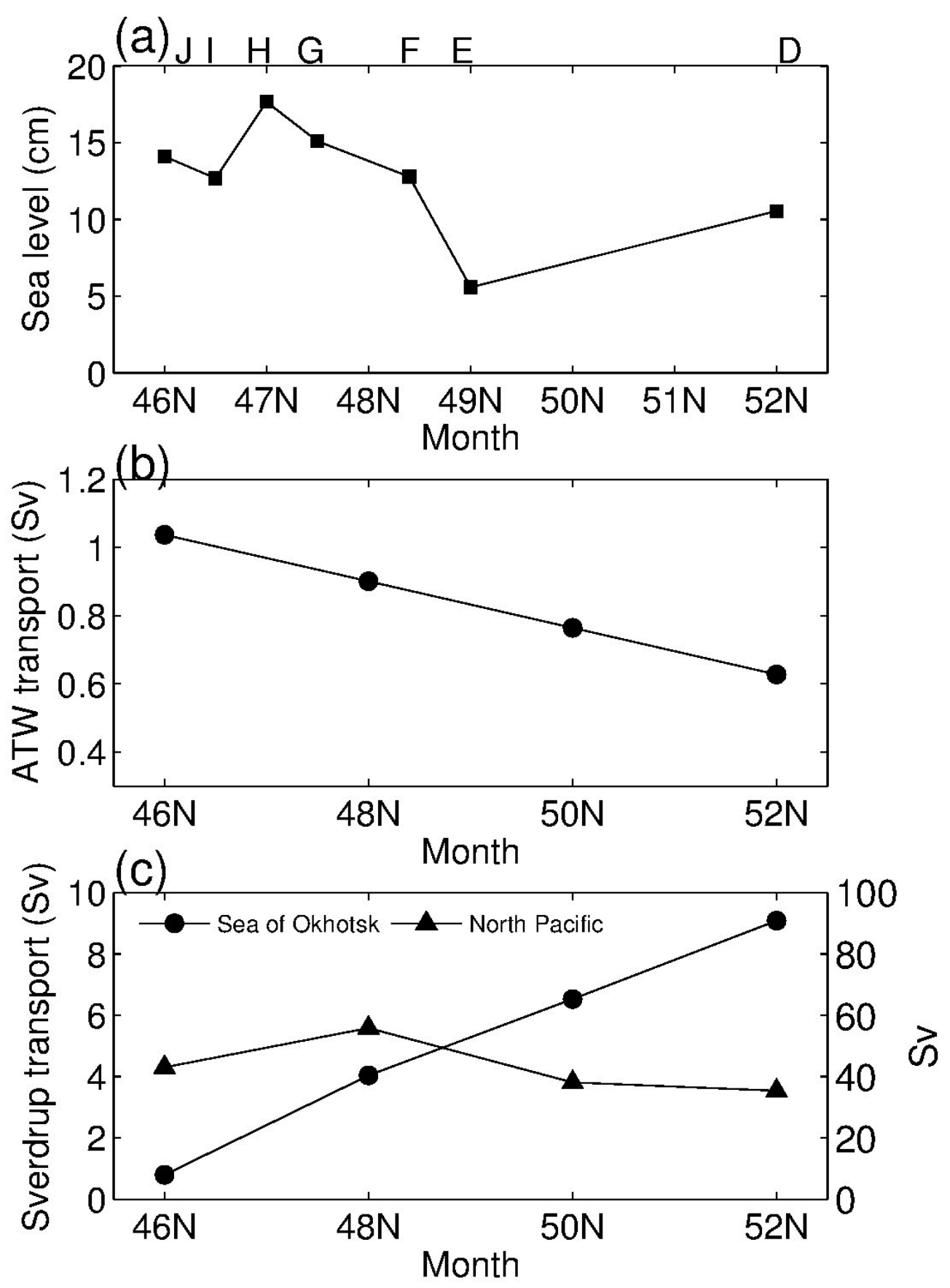

982

$983 \quad$ Figure 7. 


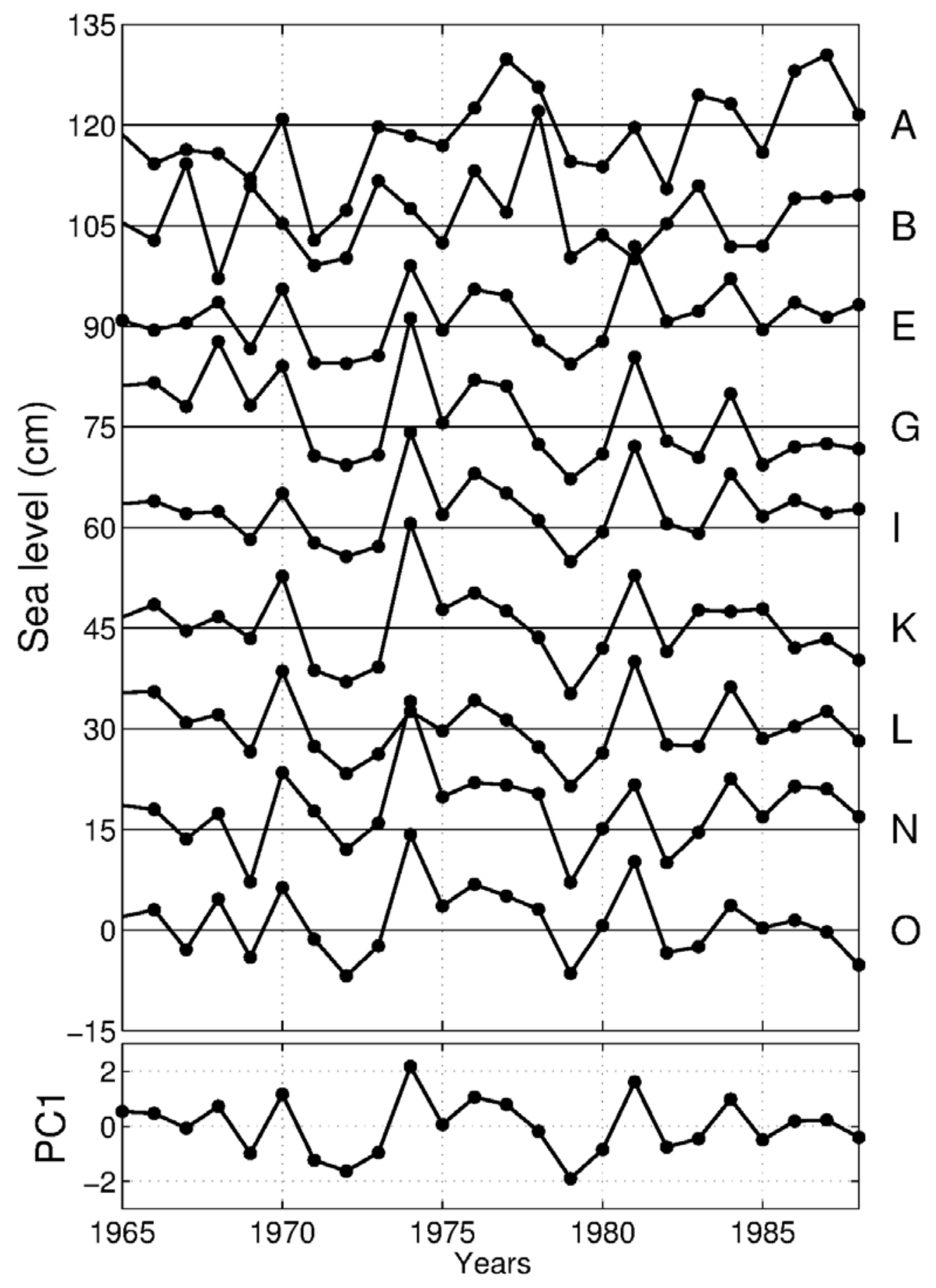

$985 \quad$ Figure 8. 


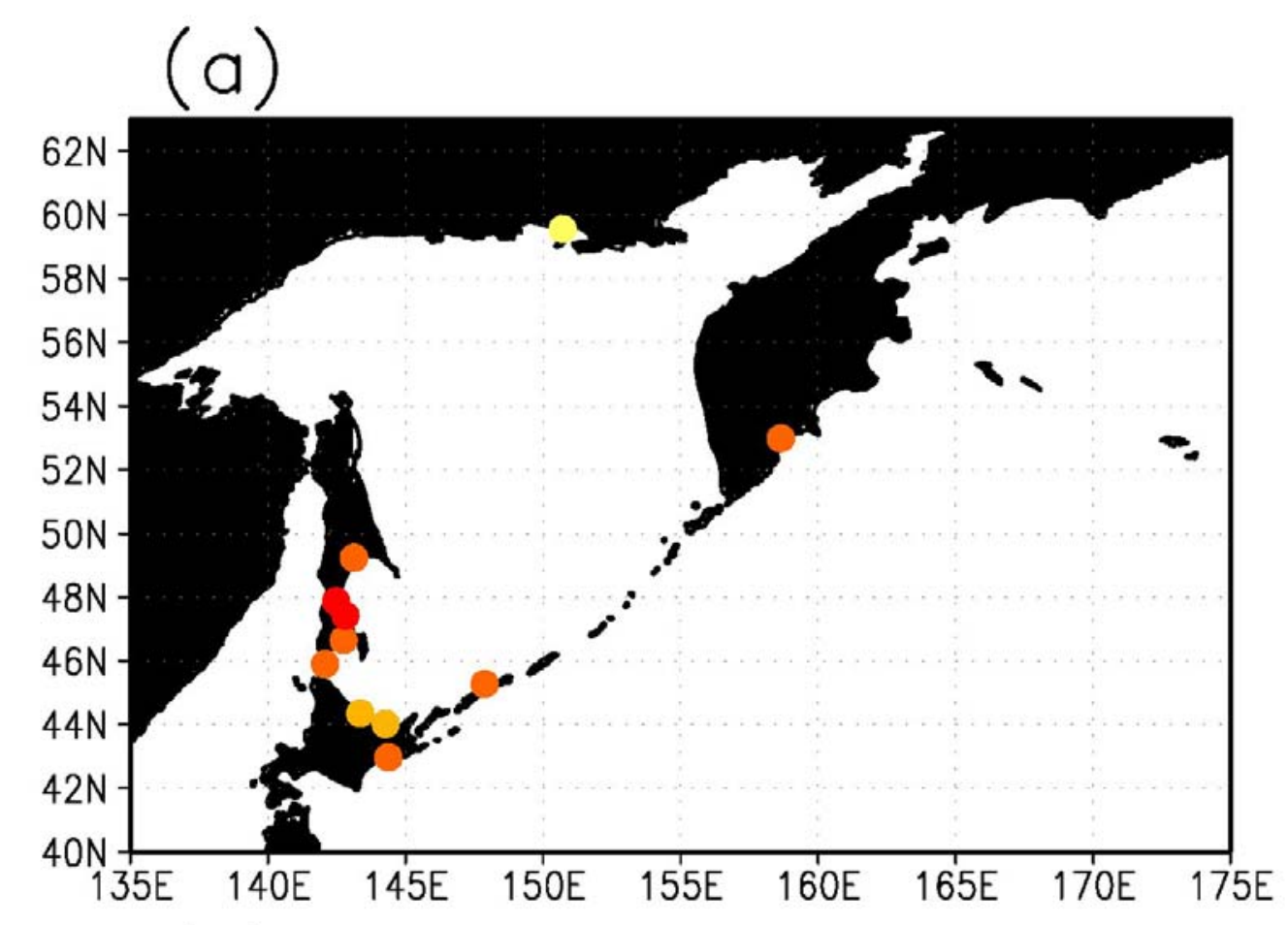

(b)

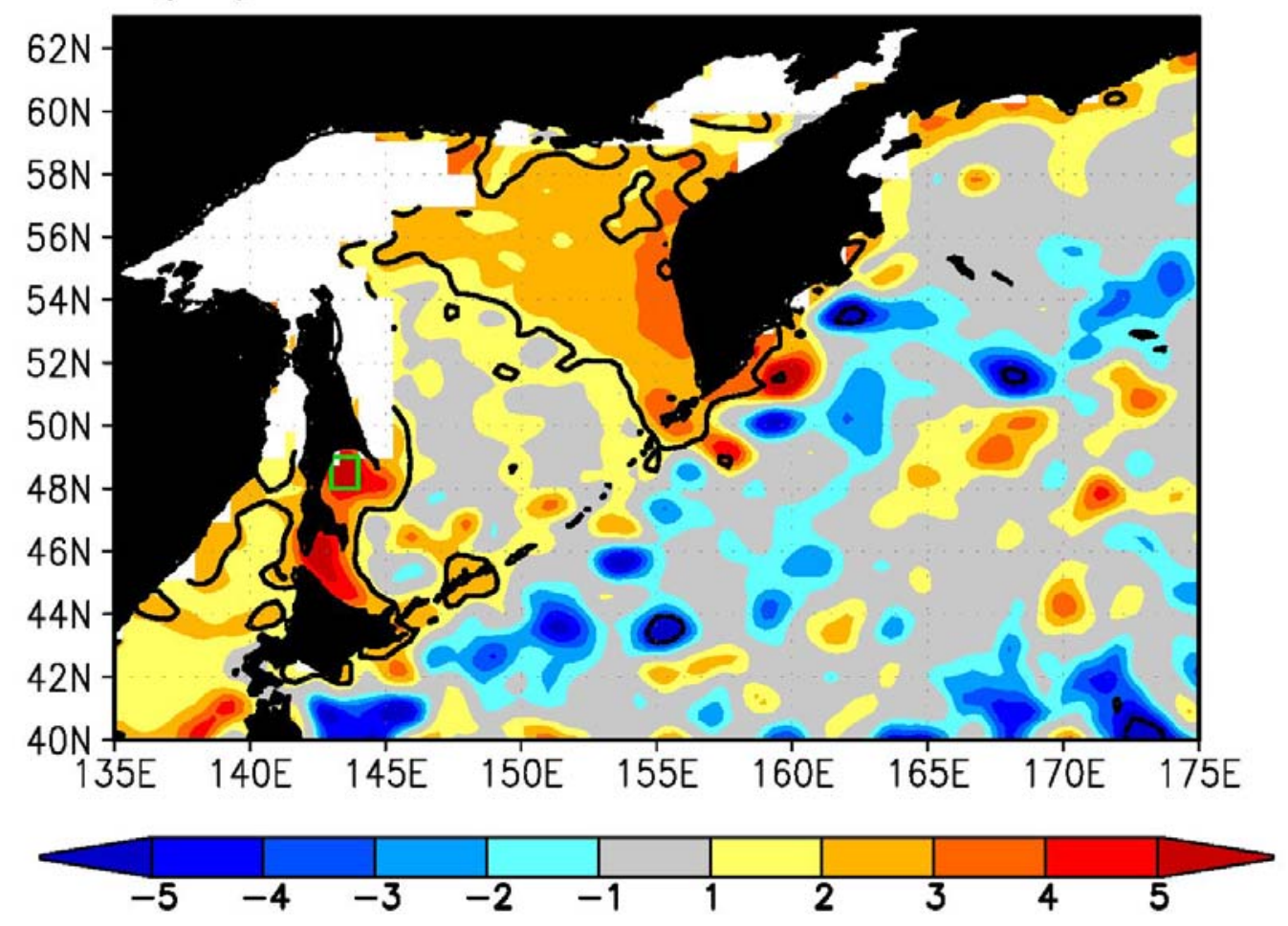

Figure 9. 


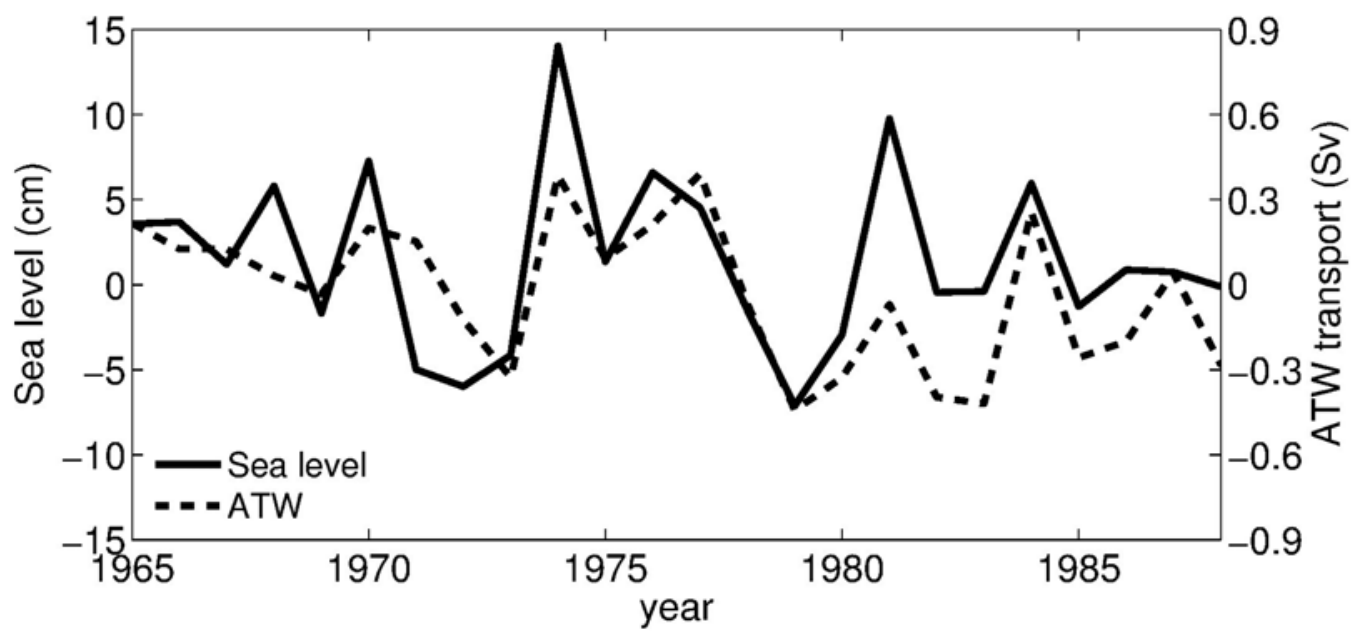

988

989 Figure 10. 
(a) Wind stress

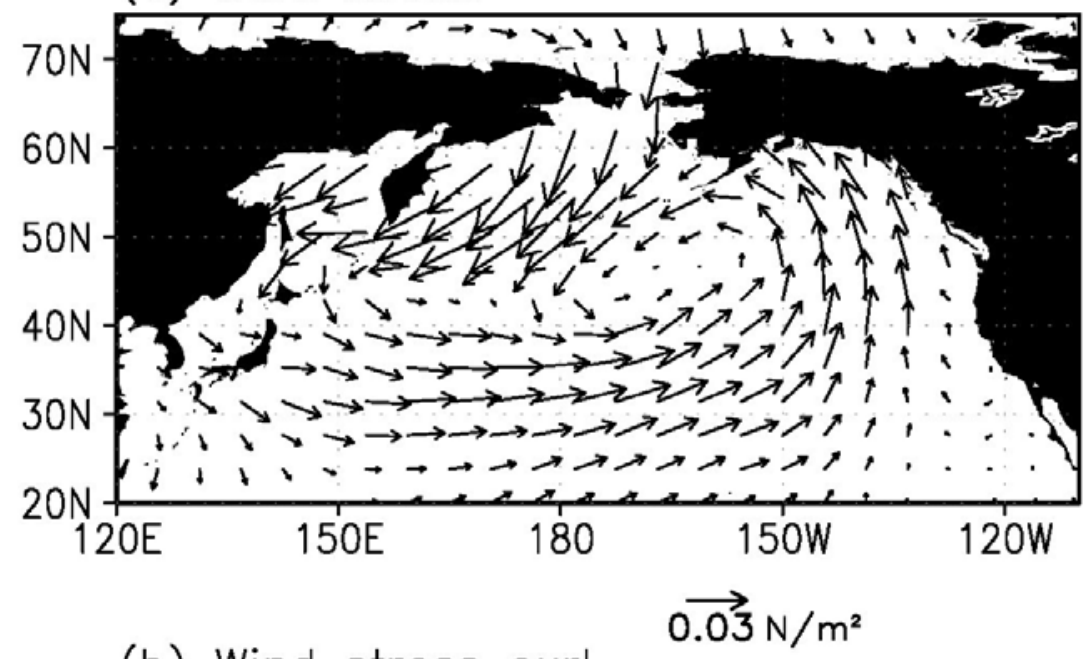

(b) Wind stress curl

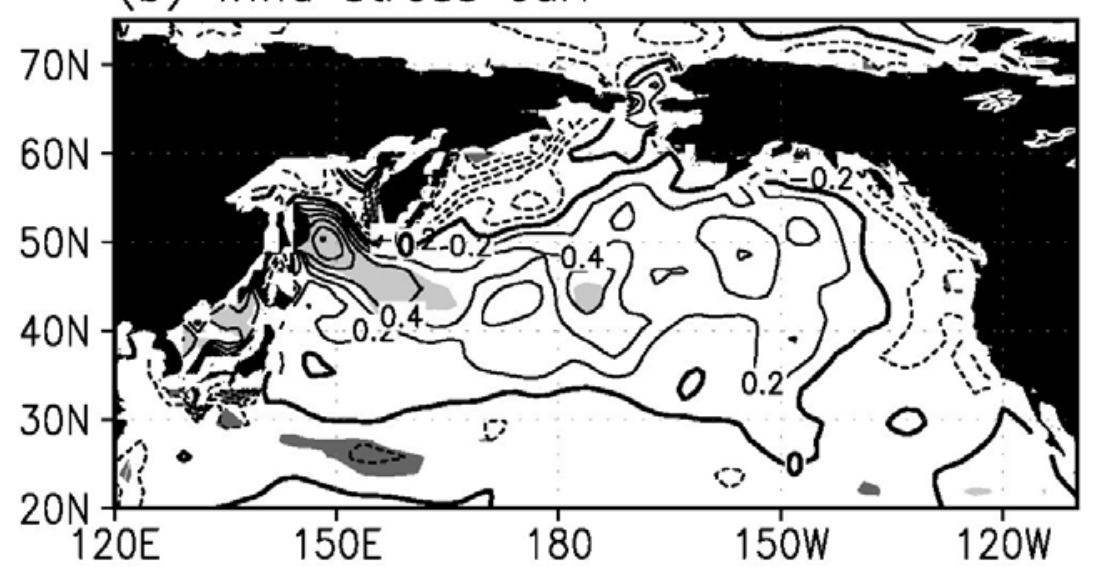

(c) Sea level pressure

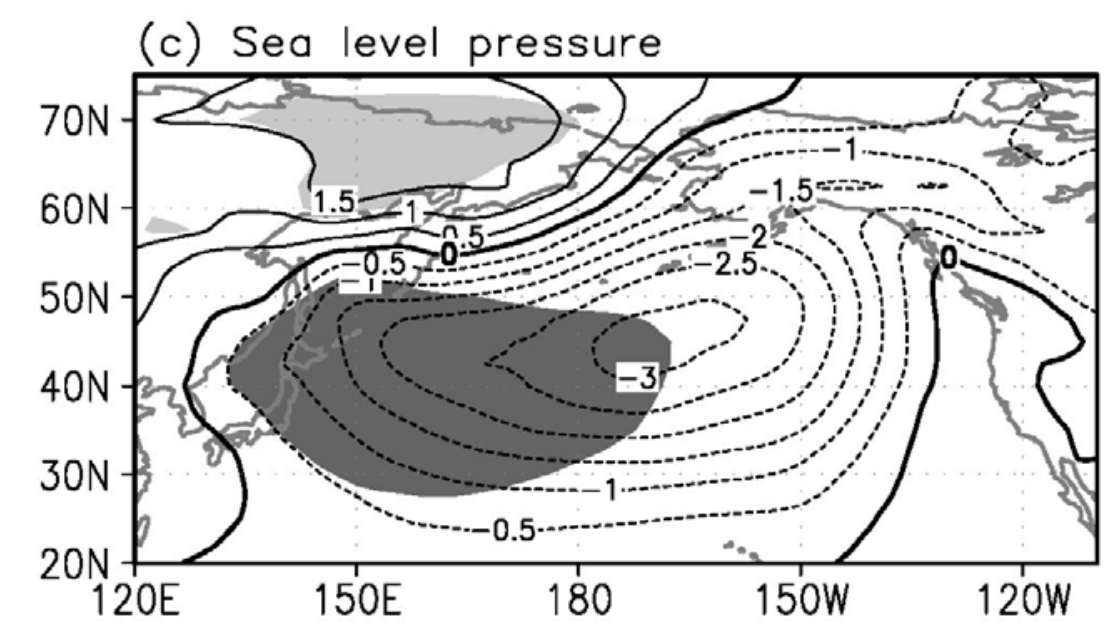

990

$991 \quad$ Figure 11. 


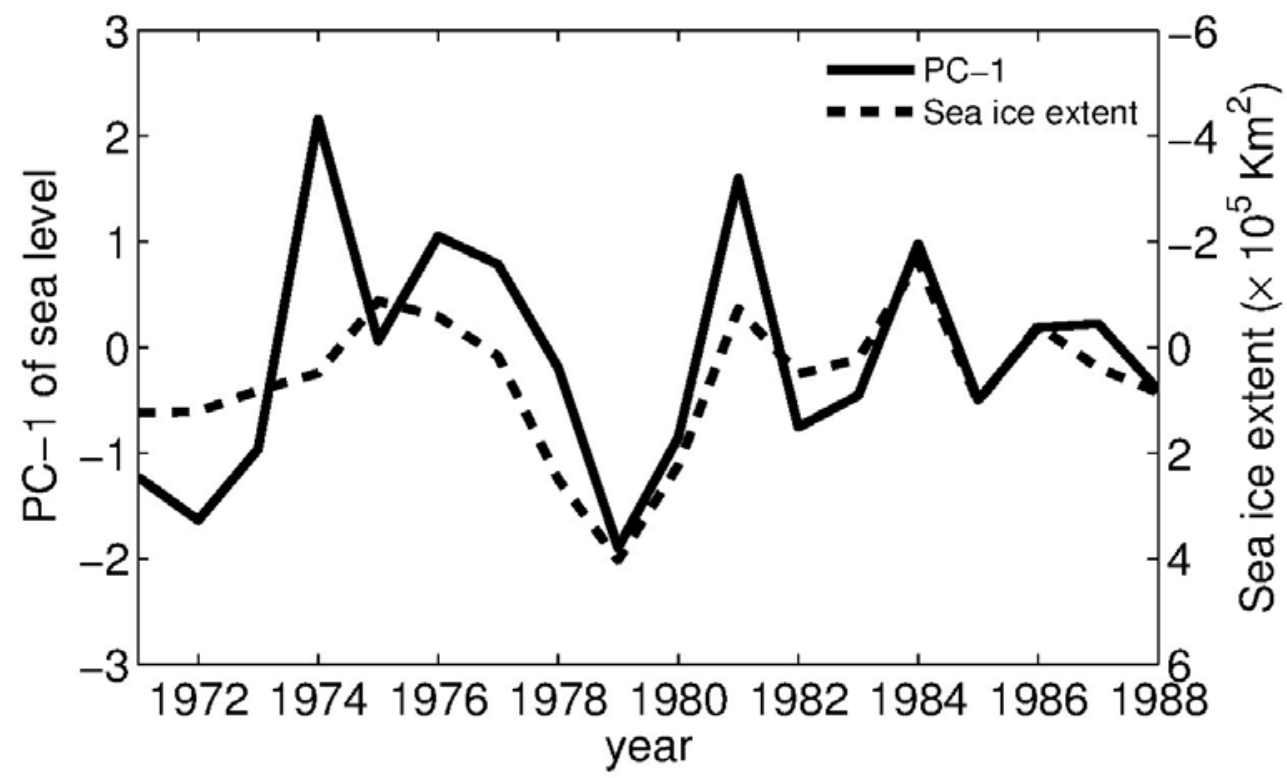

992

993 Figure 12. 